\title{
Social Security Enrollment as an Indicator of State Fragility and Legitimacy: A Field Experiment in Maghreb Countries
}

\author{
Walid Merouani ${ }^{1,2, *(D)}$, Claire El Moudden ${ }^{2}$ and Nacer Eddine Hammouda ${ }^{3}$ (D) \\ 1 Research Center in Applied Economics for Development, Alger 16000, Algeria \\ 2 Research Center in Economics and Management, 14032 Caen, France; claire.elmoudden@unicaen.fr \\ 3 National Committee of Population, Alger 16000, Algeria; nacereddine.hammouda@ensae.org \\ * Correspondence: merouaniwalid@hotmail.fr
}

Citation: Merouani, Walid, Claire El Moudden, and Nacer Eddine Hammouda. 2021. Social Security Enrollment as an Indicator of State Fragility and Legitimacy: A Field Experiment in Maghreb Countries. Social Sciences 10: 266. https:// doi.org/10.3390/socsci10070266

Academic Editors: Timo Kivimaki and Rana Jawad

Received: 12 April 2021

Accepted: 1 July 2021

Published: 9 July 2021

Publisher's Note: MDPI stays neutral with regard to jurisdictional claims in published maps and institutional affiliations.

Copyright: (c) 2021 by the authors. Licensee MDPI, Basel, Switzerland. This article is an open access article distributed under the terms and conditions of the Creative Commons Attribution (CC BY) license (https:// creativecommons.org/licenses/by/ $4.0 /)$.

\begin{abstract}
State legitimacy and effectiveness can be observed in the state's approach to delivering welfare to citizens, thus mitigating social grievances and avoiding conflicts. Social security systems in the Maghreb countries are relatively similar in their architecture and aim to provide social insurance to all the workers in the labor market. However, they suffer from the same main problem: a low rate of enrollment of workers. Many workers (employees and self-employed) work informally without any social security coverage. The issue of whether informal jobs are chosen voluntarily by workers or as a strategy of last resort is controversial. Many authors recognize that the informal sector is heterogeneous and assume that it is made up of (1) workers who voluntarily choose it, and (2) others who are pushed into it because of entry barriers to the formal sector. The former assumption tells us much about state legitimacy/attractiveness, and the latter is used to inform state effectiveness in delivering welfare. Using the Sahwa survey and discrete choice models, this article confirms the heterogeneity of the informal labor market in three Maghreb countries: Algeria, Morocco, and Tunisia. Furthermore, this article highlights the profiles of workers who voluntarily choose informality, an aspect that is missing from previous studies. Finally, this article proposes policy recommendations in order to extend social security to informal workers and to include them in the formal labor market.
\end{abstract}

Keywords: informal employment; social security; state effectiveness; Maghreb countries; individual preferences; discrete choice model

\section{Introduction}

In his seminal contribution to understanding the mechanisms of employment informality in developing countries, Maloney (2004) highlights the cost of social protection for impoverished workers. Given the low quality of services in many developing countries, mandatory contributions can be disadvantageous.

Alternative explanations include that given by Lopez (1970), who postulates that individuals will choose an informal job if they do not have access to a formal one, and that of Fields (1990), who shows that informal employment can be chosen for its easy access and flexibility of work. Günther and Launov (2012) show that the informal labor market is partly composed of workers who find the informality attractive and others that use it as a last-resort opportunity. Shehu and Nilsson (2014) highlight the socio-demographic determinants of informality, showing the impact of certain variables on the probability of being enrolled in social security systems.

In line with ILO (2003), this article defines informal employment as employment that is not enrolled with social security. We tackle the issue of low social security enrollment in three Arab countries (Algeria, Morocco, and Tunisia), and try, for the first time in the studied countries, to link it to issues of state fragility/strength and grievance. Indeed, state fragility/strength is defined as the state's ability to offer effective and legitimate governance in the social, economic, political, and security realm (Marshall and Elzinga-Marshall 2017). 
Hence, the inability of the state to deliver effective social protection to workers could make its fragility debatable.

This article will show that some categories of workers are excluded from social security, while others choose voluntary informality and prefer not to be enrolled in social security. This article considers the ratio of informal workers to total workers as an indicator of the lack of legitimacy of governance of social protection (and thus one element of state fragility). On the other hand, exclusion from social security is viewed as an indicator of a lack of efficiency of social governance (and thus an indicator of state fragility). In both cases, the non-enrollment in social security/informality brings social risks and therefore potential grievances. Hence, this problem of social security of workers and the social protection coverage of populations in general would have a conflicting effect. To suit the purpose of this paper, we propose a slightly modified definition of conflict ${ }^{1}$ and consider conflict as a contested incompatibility that concerns politics (or political and economic competition), and results in some intentional harm that conflicting parties use against each other. Indeed, according to Gurr (1970), one of the causes of conflict is "relative deprivation", such as not having access to the welfare state advantages (health, education, and social security coverage), which sometimes results in motives to rebel and initiate conflict. Hence, this article relates to the entire triangle of "state fragility-grievance-conflict" for this Special Issue.

The methodology is based on an estimation of discrete choice models used to study the determinants of informality. We rely on an original survey (Sahwa), which provides a unique opportunity for cross-country comparative analysis. The dataset covers 10,000 young people (15-29 years old) in five Arabic countries. It measures variables in the labor market, which are demographics, values, confidence in government, and institutions and the importance of religion.

Our main focus is on the reasons for not participating in social security schemes. Some respondents declare that they choose to work informally to avoid income reductions, or because they are simply not interested in social security coverage. Other workers declare that they are excluded from social insurance because their employers do not want to declare them to social security; in some cases, the employers themselves are not insured.

The likelihood of choosing informality varies according to socio-demographic characteristics and other behavioral variables, such as confidence in the government and job satisfaction.

Our findings clearly show that job satisfaction would have a negative effect on the workers' willingness to choose informality. Furthermore, we show that income has a negative effect on the probability of choosing informality for the second and third quartiles of workers. However, this effect is positive for the last quartile. Informality is also more likely to be chosen in the agricultural sector. Though education may have a negative effect on informality, it has a positive effect on the probability of choosing it. The probability of choosing informality is greater for risk-averse and individualistic workers. Finally, the cross-country comparison shows that informality is more likely to be chosen in Morocco and Tunisia.

The empirical verification of the aforementioned postulate allows policymakers to assist the excluded workers and encourage free riders who choose informality to participate in social insurance schemes.

Extending social security could be made using a Beveridgian strategy ${ }^{2}$ and assistance programs for people who are excluded, particularly women, poorly educated people, temporary salaried workers, family workers, low-income workers, and single people, as revealed in our empirical results. However, the governments of the investigated countries should also provide some incentives to increase the willingness of free riders to participate in the social insurance scheme. These incentives may target male, highly educated, and self-employed workers and employers, and workers with a high income (fourth quartile).

The remainder of this article is organized as follows: Section 2 describes social security systems in the three countries studied; Section 3 reviews the theoretical and empirical studies 
that deal with informality; Section 4 provides a description of the data and the econometric approach; Section 5 presents the empirical results; Section 6 presents the conclusions.

\section{Social Security Systems in the Maghreb Countries}

Social security systems across the Maghreb countries are quite similar. They are straightforward and are provided by only one basic public pillar. The systems are corporatist and contributive. In every country, there is a set of insurance funds that cover workers against different categories of social risks. We will expand upon this in detail in the following section.

\subsection{Algeria}

The Algerian social security system is made up of five insurance funds that offer coverage against all social risks (sickness, maternity, accident and injury at work, death, disability, unemployment ${ }^{3}$, and retirement). The first found is the "Caisse Nationale des Assurances Sociales des Travailleurs Salariés" (CNAS). This fund covers employees against sickness, maternity leave, accidents at work, and invalidity. The rate of contribution to this fund is $34 \%$ of one's monthly wage (9\% supported by the employee, and the rest by the employer). A total of $18.75 \%$ of this sum is paid to the pension fund "Caisse Nationale des Retraites" (CNR). It administers pensions of salaried workers of the public and private sectors. It offers a pension with a maximum replacement rate of $80 \%$ of the mean of the five best wages of one's active life (reference wage). On the other hand, the self-employed and employers have to buy insurance from the "La Caisse Nationale de Sécurité Sociale des Non-Salariés" (CASNOS). This fund covers those insured against the same risks as does the CNAS, with the exception of maternity leave and accidents at work. CASNOS also administers a pension scheme for non-salaried workers. The contribution rate to CASNOS is $15 \%$ of the annual income of the self-employed. However, there is a possibility for workers to pay a fixed amount of DZD 32,400 per year if annual revenue is not declared by the self-employed. The replacement rate provided by CASNOS is the same $(80 \%)$ as the CNR replacement rate. However, the retirement age is 65 years old ( 60 for women) for the self-employed, as opposed to 60 years ( 55 years for women) for employees. The last two insurance funds are the "Caisse Nationale des Conges Payés et du Chomage-Intempéries des Secteurs du Batiment, des Travaux Publics et de l'Hydraulique" (CACOBATH) and "Caisse Nationale d'Assurance Chômage" (CNAC). These funds cover, respectively, leave caused by bad weather in the construction sector and the unemployment risks of employees with permanent contracts (Merouani et al. 2014; Merouani 2014).

\subsection{Morocco}

The social security system in Morocco provides coverage against all social risks. It comprises the "Caisse Nationale de Sécurité Sociale" (CNSS), "L'Agence Nationale d'Assurance Maladie" (ANAM), and "La Caisse Nationale des Organismes de Prévoyance Sociale" (CNOPS). These last three funds cover salaried workers of the public and private sectors against all social risks (sickness, maternity leave, work injury and accidents at work, invalidity, and death). The contribution rate to social security in Morocco is $28.40 \%$ of the wage ( $21.47 \%$ paid by the employer). A total of $11.89 \%$ of this contribution is used to finance pensions that are administered by the "Caisse Marocaine des Retraites" (CMR). The maximum replacement rate of the pension system in Morocco can reach $100 \%$ for employees of the public sector, and $70 \%$ for the employees of the private sector. The latter group can also subscribe to a supplementary pension scheme that is administered by the “Caisse Interprofessionnelle Marocaine de Retraite" (Dupuis et al. 2011). Furthermore, the government established a law in 2010 (law no. 03-07) entitling the self-employed to the social security system. However, this law is not yet applied, which means that the self-employed can only be insured through voluntary insurance in the market. This voluntary insurance charges the insured person $12.89 \%$ and $4.52 \%$ for pension and health insurance, respectively. 


\subsection{Tunisia}

The Tunisian social security system is made up of two main schemes: the schemes for salaried workers and the schemes for non-salaried workers. The first one is administered by the "Caisse Nationale de Sécurité Sociale". This fund provides insurance against invalidity, death, and unemployment, and also provides pensions and family allowance. Health insurance for employees is administered by the "Caisse Nationale d'Assurance Maladie" (CNAM). This fund provides coverage against sickness, maternity leave, and work injury

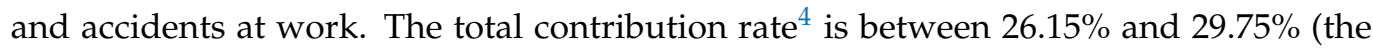
employer's share is between $16.97 \%$ and $20.57 \%$ ). A total of $12.5 \%$ of the contribution goes to retirement insurance. The maximum replacement rate for pensions is $90 \%$ and $80 \%$ for the employees of the public and private sectors, respectively. The legal age of retirement is 60; however, due to pre-retirement possibilities, the average age of retirement is 58 (Ben Othman and Marouani 2016). Furthermore, there is a pension fund for public sector workers called the "Caisse Nationale de Retraite et de Prévoyance Sociale" (CNRPS). This fund administers pensions and death insurance for public sector workers.

The Tunisian social security system also includes the self-employed scheme; it is administered by the same fund as that for employees. Enrollment in CNSS and CNAM is mandatory for the self-employed. However, the insurance against accidents at work and work injury is voluntary. The contribution for self-employed workers is about $14.71 \%$ of the declared income. The pension replacement rate varies from $30 \%$ of the average income of the 10 first years of their active life to $80 \%$ if the workers have contributed for 35 years.

In order to extend coverage, Tunisia improved its social security system in 2002 by creating a special scheme for low-income workers and a special scheme for artists and intellectuals (Ben Braham and Marouani 2016).

\section{Literature Review on Informal Employment}

A general observation in developing countries is the coexistence of a small formal and a large informal labor market. The first segment is usually well organized and is covered by social security systems. However, the second segment (the informal labor market) is not covered by social security (Assaad 2014) The theoretical background of informal employment has been assessed by four main schools of economic thought. Firstly, the dualist school sees the informal sector as covering marginal activities that provide income to the poorest population. This school considers informal workers to be excluded from the modern economy (Hart 1973; ILO 1972). Secondly, the structuralist school claims that the informal market is made up of subordinate microenterprises and workers that reduce the input and labor cost of larger enterprises. This school considers that informality is driven by the willingness of firms (capitalists) to reduce labor costs and evade taxes (Castells and Portes 1989). Thirdly, the legalist school sees informality as microentrepreneurs that choose to work informally to avoid costs, as well as to avoid the time and effort associated with formal registration (De Soto 1989). Lastly, the voluntarist school has the same view as the legalist school but does not blame the cumbersome nature of the registration process (Chen 2012). While each school considers informal employment and its causes in different ways, the recent literature argues that those theories are complementary (Huang et al. 2020) and need to be combined in order to better understand informality (Chen 2012). This article argues that the informal labor market is heterogeneous and is explained by many factors. Each theory mentioned above could be suitable to a particular category of informal workers, according to their profile.

Following the above theories, the empirical literature has investigated whether informal employment is chosen voluntarily or whether people are pushed into it because of the barriers that prevent them from accessing formal jobs (Günther and Launov 2012). The majority of researchers argue that the informal labor market is composed of individuals who choose informality and others who do not. Lopez (1970) argues that individuals may choose informal employment if they find barriers that prevent them from accessing a formal one. For instance, Perry et al. (2007) found that there are two lenses through which 
one can view informality: exclusion and exit. Under the first lens, informal workers are viewed as being excluded from state benefits or from the circuit of the modern economy. Under the second lens, informal workers may be viewed as individuals/households who have conducted their own cost-benefit analysis of the formality and decide their optimal level of engagement with governmental institutions. High informality would be the result of a low level of engagement. The authors argue that the two lenses are complementary. Lastly, the authors highlight that the exclusionary mechanisms may be more important in some countries and exit mechanisms may be more important in others. The last point will be tackled in this article by comparing the cases of Algeria, Morocco, and Tunisia.

In a study on the Indian labor market, Duggal (2006) stipulates that the unemployed apply a strategy of "let's start with something"; in this sense, they choose any kind of job (including an informal job without social security coverage). Falco (2013) shows that the unemployed must often choose between formal employment with difficult access and informal jobs with easy access. Renana (1998) shows that in India, social security is not a priority for workers. A popular expression used by female workers goes: "Let us earn enough income and we can take care of all our other needs". These women prefer economic security (income) rather than social security. This preference may be due to behavioral factors such as myopia and uncertainty surrounding social risks and the offer of benefits. Other researchers have analyzed job satisfaction in the formal and informal sectors; Razafindrakoto et al. (2012) explored the Vietnamese workplace. They show that $39 \%$ of informal workers are satisfied with their job; 50\% declare that they are neither satisfied nor dissatisfied; and less than $10 \%$ declare that they are not satisfied. These results show the heterogeneity of labor markets and the need for further research to identify who is truly satisfied with an informal job, as we will show in the present article. Fields $(1975,1990)$ led a study on informal workers in Malaysia and Costa Rica. He shows that informal workers are satisfied with their job, and they do not want to look for formal employment. According to Fields, people choose informal employment for many reasons, such as ease of access, and also because informal employment does not require a high level of education or a high cash flow. This sort of flexibility leaves time for workers to look for another, better job (Fields 1990). De Soto (1989) argues that choosing informality is a rational behavior adopted by the self-employed to escape the bureaucratic burdens and costs of formality. Others consider informality to be a result of a strategy of multinational firms that tend to employ local workers without social security coverage in order to minimize their costs of labor (Moser 1978; Portes et al. 1989).

Banerjee (1983) shows that $41 \%$ of informal workers in India are looking for a new job; Banerjee has interpreted this result as evidence of labor market segmentation, which was attributed, in part, to imperfect information. A similar result was found by Rhee (1986) in South Korea. By applying an econometric model to seven Latin American countries, Auerbach et al. (2007) show that low social security coverage is the result of the workers' unwillingness to participate in this system.

Some studies on the mobility of workers in labor markets show that workers may move from formal to informal jobs; Bellache (2010) shows through a survey in the region of Bejaia (Algeria) that a high proportion ( $42 \%$ ) of informal workers have left a formal job. Maloney (2004) shows that among formal workers who move to the informal sector in Mexico, two-thirds move voluntarily, looking for more independence or higher incomes. He assumes that informal employment may be chosen by individuals for the desirable non-wage features; those individuals maximize their utility rather than their income. Mazumdar (1981) and Balan et al. (1975) led a study in Malaysia and Mexico, respectively; they both show that workers leave formal jobs to occupy informal ones. The authors argue that informal jobs offer more flexible hours of work and sometimes a higher income than formal employment.

A more recent study in the MENA region (in Lebanon, Morocco, Syria, and Jordan) shows heterogeneity among the behaviors of workers in the labor market (Gatti et al. 2014). The authors investigated whether or not the workers are seeking a new job. The findings 
show that while informal workers are more likely to be willing to change their jobs, less than half of them want to change or are looking for other jobs: $45 \%$ of the informal workers in Lebanon (36.9\% in Egypt and 34.4\% in Syria) are looking for a new job, which confirms behavioral heterogeneity between workers with regards to informality. Furthermore, Gatti et al. (2014) framed this heterogeneity as a difference between informal self-employed workers and informal employee workers; they claim that self-employed people may voluntarily choose informality.

Focusing on the informality of enterprises, De Mel et al. (2013) have been looking for potential incentives that push informal enterprises in Sri Lanka to register. They found that neither information nor reimbursement of the registration fees increased the registration rate. Only cash transfers for enterprises have been found to incentivize enterprises to register; the higher the amount of cash, the higher the likelihood of registration.

In light of this literature, we argue that there are two main concepts with regard to the origin of informal employment: the first one notes that informal employment is chosen voluntarily, and the second one perceives informal employment as an activity of subsistence and a strategy of last resort. We believe that the two views can be simultaneously true. The following section is concerned with the identification of the individual characteristics of those who chose informality. We will also reveal the characteristics of workers who are pushed involuntarily into informal employment. To do so, we rely on the Sahwa dataset.

\section{Data and Econometric Approach}

\subsection{Data}

This article uses the Sahwa dataset, which is created from a representative survey covering 10,000 households in five Arabic countries: Algeria, Egypt, Lebanon, Morocco, and Tunisia. The sample was chosen using stratified sampling. Conducted in 2016, this survey focuses on youth empowerment and analyzes the situation of one young person (15-29 years old) from each household. This adds up to 2000 young people per country, and 10,000 young respondents in the total sample. In the present article, we focus only on active young workers in the three Maghreb countries (Algeria, Morocco, and Tunisia), reducing our sample to 1525 . We are focusing on the issue of enrolment in social security. We adopted the ILO definition of informality, that informal employment is employment not covered by the social security system.

To clean our dataset, we removed some incoherent results. We deleted those who are self-employed and who declare that they are not insured because their employers do not want to declare them. Despite this reduction in subjects, the size of the sample allowed for econometric modeling.

\subsection{Econometric Approach}

In order to uncover the factors causing workers to choose informality, we estimated a weighted logit model for the entire sample, including the three countries mentioned ${ }^{5}$. We used weighting to obtain a representative result for all the population. Weighting is used in surveys to show how many people out of the total population are represented by the surveyed person. This variable (weight) is larger than one for under-represented groups, and smaller than one for over-represented groups ${ }^{6}$.

As mentioned, we utilized a $\operatorname{logit}^{7}$ model, which allowed us to estimate the impact of socio-demographic variables on the likelihood of choosing informality.

$$
C H_{i}=\beta+a S D_{i}+\varepsilon_{i}
$$

The dependent variable of choosing informality was measured using the following question: "Why are you not affiliated to the social security system?" The choices were:

My employer does not want to declare me;

My employer is not insured;

I am not interested in social security; 
To avoid a decrease in my salary/earnings.

We grouped the first two answers in the category of "excluded" and the last two categories ${ }^{8}$ in the group of "chosen informality". $S D_{i}$ is a vector of socio-demographic variables. Hence, a collinearity problem can arise in the model. We resolve this problem in this article by measuring the variation inflation factor (VIF). This factor measures the inflation of the coefficients of the model induced by the correlation between the independent variables. Collinearity occurs when the VIF is greater than 10 (Mansfield and Helms 1981).

Finally, in order to obtain more precise results, we measured interaction effects in the logit model. Interaction effects measure the effect of two independent variables simultaneously on the probability of choosing informality. This calculation can be formalized with the following equation:

$$
y=a+\beta_{1} X_{1}+\beta_{2} X_{2}+\beta_{3} X_{1} X_{2}+\varepsilon
$$

Analyzing the interaction effect consists of the interpretation of $\beta_{3}$, which measures the impact of $X_{2}$ on $y$ controlling for $X_{1}$. For example, if $y$ is the variable that measures the probability of acquiring a disease, $X_{2}$ is a dummy variable of "smoking", which takes the value 1 if the individual smokes. $X_{1}$ is the gender variable. In the model below, $\beta_{3}$ would measure the impact of smoking on the likelihood of women becoming sick.

\section{The Empirical Results}

\subsection{Who Are the Free Riders? Disruptive Statistics}

As is well known from employment surveys in the studied societies, the Sahwa survey confirms the low rate of participation in the social security system. Among 1525 workers in the three countries, only 485 (31\%) participate. Low participation is observed in the three countries; the participation rate in social security (formality) is about $41 \%$ in Algeria, $21 \%$ in Morocco, and 30\% in Tunisia. These proportions constitute the formal employment of the labor market. According to Günther and Launov (2012), income provided for the respective employments (formal and informal) can be a determinant of individual choices. We present the logarithm for the distribution of income for formal and informal employment in the following figure (Figure 1):

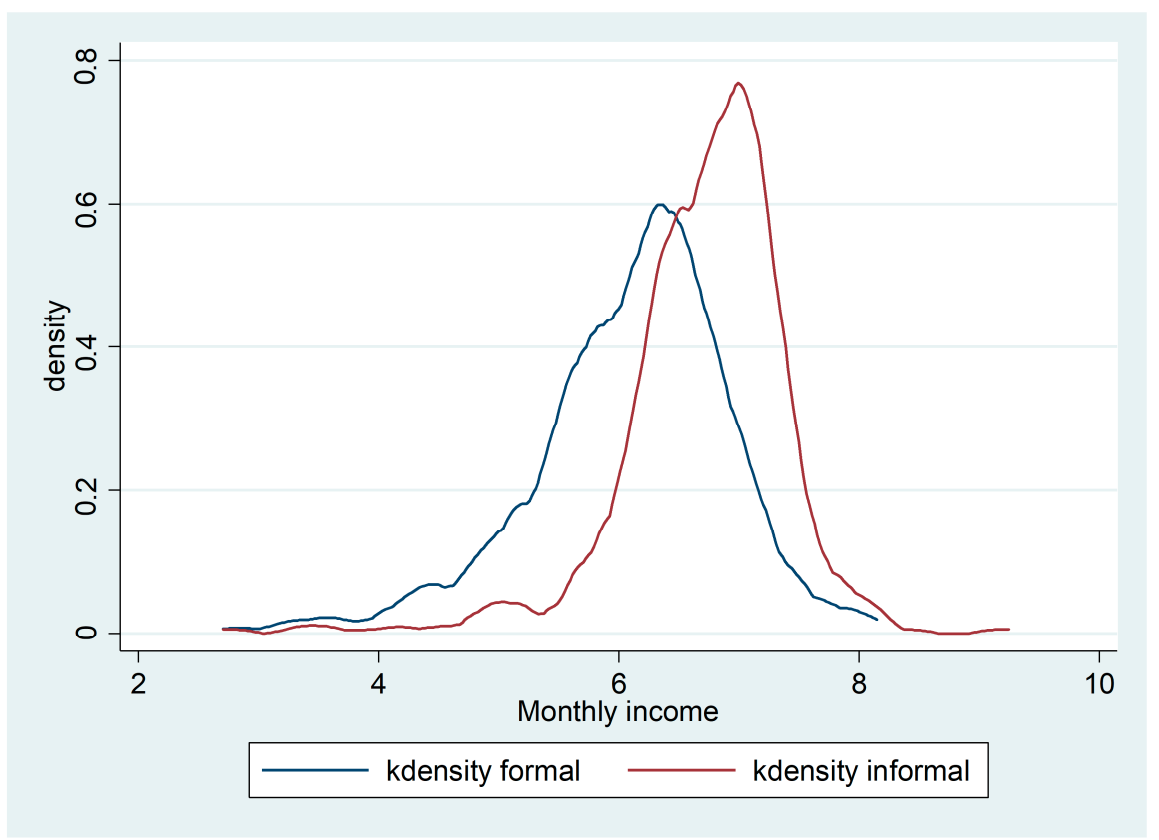

Figure 1. Densities of monthly log income for the three countries. Source: Sahwa dataset using Stata. 
The figure above shows that formal and informal incomes overlap for the three countries, and it also demonstrates that not all informal workers earn less than formal workers. This result seems valid ${ }^{9}$ for all countries when studied separately (see Figure A1 in Appendix A). Our finding is in line with that of Günther and Launov (2012), from their study in which the authors plot the wages of formal and informal workers in the Ivory Coast.

The reasons for not being insured are summarized in the following table (Table 1).

Table 1. Reasons for not being insured (\%). Source: Sahwa dataset using Stata.

\begin{tabular}{ccccc}
\hline & Algeria & Morocco & Tunisia & Total \\
\hline Employer refuses to insure me & 11.46 & 13.28 & 11.14 & 11.97 \\
I am not interested & 35.29 & 59.6 & 41.23 & 45.66 \\
Reduction in my salary/earnings & 9.29 & 16.95 & 15.88 & 14.19 \\
Employer is not insured & 23.22 & 9.6 & 13.09 & 15.06 \\
Other (specify) & 20.74 & 0.56 & 18.66 & 13.13 \\
Total & 100 & 100 & 100 & 100 \\
\hline
\end{tabular}

The table above shows that a large percentage of the respondents $(46 \%)$ are not interested in social security. A total of $14 \%$ of workers are not enrolled in order to avoid reductions in their earning; $12 \%$ and $15 \%$ of the workers declare that their employer is not insured or does not want to insure them. These workers are thus excluded from the social security system.

In order to simplify the interpretation of our results, we grouped the four categories into two larger categories, distinguishing between workers who choose ${ }^{10}$ informality and those who are excluded ${ }^{11}$ from the social security system. The result shows that $69 \%$ of the workers would choose informality. The rest of the workers (31\%) would be excluded. The proportion of workers that choose informality varies across countries: it amounts to $56 \%$ in Algeria, 77\% in Morocco, and 70\% in Tunisia.

The summary statistics of the survey show that informality is a choice made by workers in both rural and urban areas. More specifically, $70 \%$ and $67 \%$ of the workers in the rural and urban areas, respectively, may choose informality. The highly educated seem to be more likely to choose informality; $73 \%$ of people with secondary and higher education qualifications report that they are not interested in social security or they want to avoid a decrease in income, and hence they may choose informality. This number is about $66 \%$ for those with a low and medium level of education. This result may be due to the fact that highly educated people are more likely to understand social security rules and ultimately understand that enrolment in the system is not necessarily beneficial. Indeed, the contribution rate is still high (35\% in Algeria for instance), but the benefits that enrolled people can obtain from the system are low (Merouani et al. 2016a). Marital status analysis shows that $75 \%$ of married workers prefer informality, while $68 \%$ of singles choose informality $^{12}$. Given that self-employed workers do not depend on an employer to enroll in social security, those who are not enrolled in the system have indeed chosen informality.

With regard to confidence in their government, we found that $67 \%$ of the people who choose informality report that they are not confident in the government, which means that confidence in the government might be a significant determinant of choosing informality so as to avoid the public social security system. This article also analyzes the correlation between the variable of choosing informality and the job satisfaction variable; the results show that $62 \%$ of workers who choose informality report that they are satisfied with their job and $38 \%$ are not satisfied ${ }^{13}$. Hence, one might think that workers could prefer an informal job for the satisfaction that this job provides. We are also attentive in our study to household composition and its potential impact on the likelihood of choosing informality: we observe that $67 \%$ of respondents who live with their parents, and $75 \%$ of respondents who do not live with their parents, choose informality. The findings also show that when parents are not insured, children are more likely to choose informality: $72 \%$ of children with 
uninsured parents choose informality, while $65 \%$ of workers whose parents are insured choose informality.

With regard to correlations between the choice of informality and religious factors, we explore the question of the importance of religion in the place of work ${ }^{14}$ and the importance of religion in trade and financial transactions ${ }^{15}$. We found that workers who report that they are more preoccupied with religious matters are less likely to choose informality $(67 \%)$. On the other hand, $75 \%$ of workers who are not preoccupied with religion choose informality. The same correlation has been found for the importance of religion in trade and financial transactions. These results suggest that there is a potential negative effect of religion on the probability of choosing informality.

The survey provides data on the number of workers looking for a new job, and it reveals that $76 \%$ of workers who choose informality are not looking for a new job. We also study the relationship between risk aversion ${ }^{16}$ and their informality preference. This relationship shows that risk-takers are more likely to choose informality than risk-averse workers. We tested a second behavioral variable, which is altruism ${ }^{17}$. It is worth mentioning that this later variable measures respondents' self-perception of their altruism, which is not the best method to measure this behavior. Indeed, other experimental measures, such as the dictator game (Murphy et al. 2011), ultimatum game, and public good game (Faillo et al. 2013), could be used. The descriptive statistics show that this variable does not seem to affect the preference for formality or informality. The proportion of altruistic people who choose informality is practically equal to the proportion of individualistic workers who choose informality.

We display more details and descriptive statistics in Appendix A.

\subsection{Econometric Results}

The summary statistics displayed above reveal general trends and the correlation between socio-demographics and informality preference, and do not allow emphasis on the significant determinants of choosing informality. In order to obtain more precise results about the causality, we ran a weighted logit regression. As mentioned below in Section 3, firstly, this model was expected to reveal the impact of the different socio-demographic variables on the probability of being insured. Then, we ran a second model to show the determinant of informality preference. The results of the two models are presented in the table below (Table 2).

Table 2. Weighted logit model. Dependent variables: (1) affiliation to social security and (2) choosing informality. Definition/description of the independent variables can be found in Appendix A. Source: Sahwa dataset using Stata.

\section{VARIABLES}

\section{Urban}

More than secondary education

Single

2. Permanent employee

3. Non-permanent employee

4. Contributing family help
(1)

(2)

Odds Ratio Affiliation to Social Security Choosing Informality

$\begin{array}{cc}1.142 & 0.77 \\ (0.188) & (0.156) \\ 2.091^{* * *} & 1.802^{* * *} \\ (0.324) & (0.38) \\ 0.411^{* * *} & 0.887 \\ (0.105) & (0.335) \\ 6.404^{* * *} & 0.306^{* * *} \\ (1.268) & (0.12) \\ 0.879 & 0.372^{* * *} \\ (0.165) & (0.121) \\ 0.467^{* *} & \\ (0.176) & \end{array}$


Table 2. Cont

\begin{tabular}{|c|c|c|}
\hline & (1) & (2) \\
\hline VARIABLES & $\begin{array}{l}\text { Odds Ratio } \\
\text { Affiliation to Social Security }\end{array}$ & $\begin{array}{c}\text { Odds Ratio } \\
\text { Choosing Informality }\end{array}$ \\
\hline 2. Neither confident nor not confident & $\begin{array}{c}0.915 \\
(0.188)\end{array}$ & $\begin{array}{c}0.877 \\
(0.256)\end{array}$ \\
\hline 3. Confident in government & $\begin{array}{c}0.988 \\
(0.177)\end{array}$ & $\begin{array}{l}0.866 \\
(0.22)\end{array}$ \\
\hline 2. Satisfied & $\begin{array}{c}0.700 \text { * } \\
(0.13)\end{array}$ & $\begin{array}{c}0.755 \\
(0.251)\end{array}$ \\
\hline 3. Dissatisfied & $\begin{array}{c}0.512 \text { *** } \\
(0.121)\end{array}$ & $\begin{array}{l}0.507^{*} \\
(0.186)\end{array}$ \\
\hline 4. Very dissatisfied & $\begin{array}{c}0.249^{* * *} \\
(0.0833)\end{array}$ & $\begin{array}{c}0.421^{* *} \\
(0.162)\end{array}$ \\
\hline Living with parent & $\begin{array}{c}2.014 * * * \\
(0.449)\end{array}$ & $\begin{array}{c}0.76 \\
(0.211)\end{array}$ \\
\hline Parent insured & $\begin{array}{c}2.552^{* * *} \\
(0.43)\end{array}$ & $\begin{array}{c}0.781 \\
(0.157)\end{array}$ \\
\hline Female & $\begin{array}{c}1.094 \\
(0.192)\end{array}$ & $\begin{array}{c}1.028 \\
(0.255)\end{array}$ \\
\hline \multicolumn{3}{|l|}{ Religion at work ((Ref Very important) } \\
\hline 2. Important & $\begin{array}{c}0.791 \\
(0.176)\end{array}$ & $\begin{array}{c}0.9 \\
(0.245)\end{array}$ \\
\hline 3. Neither important nor unimportant & $\begin{array}{c}0.725 \\
(0.207)\end{array}$ & $\begin{array}{c}1.303 \\
(0.493)\end{array}$ \\
\hline 4. Unimportant & $\begin{array}{c}0.735 \\
(0.268)\end{array}$ & $\begin{array}{c}1.328 \\
(0.622)\end{array}$ \\
\hline 5. Not important at all & $\begin{array}{c}0.689 \\
(0.286)\end{array}$ & $\begin{array}{l}1.953 \\
(1.029)\end{array}$ \\
\hline \multicolumn{3}{|c|}{ Religion in commercial transactions (Ref Very important) } \\
\hline 2. Important & $\begin{array}{c}1.103 \\
(0.251)\end{array}$ & $\begin{array}{c}1.131 \\
(0.306)\end{array}$ \\
\hline 3. Neither important nor unimportant & $\begin{array}{l}0.634 \\
0.191\end{array}$ & $\begin{array}{l}1.418 \\
(0.516\end{array}$ \\
\hline 4. Unimportant & $\begin{array}{l}1.276 \\
(0.409)\end{array}$ & $\begin{array}{c}1.403 \\
(0.659)\end{array}$ \\
\hline 5. Not important at all & $\begin{array}{l}1.148 \\
(0.477)\end{array}$ & $\begin{array}{c}0.79 \\
(0.367)\end{array}$ \\
\hline Not looking for a new job & $\begin{array}{c}1.733^{* * *} \\
(0.303)\end{array}$ & $\begin{array}{l}1.513^{*} \\
(0.322)\end{array}$ \\
\hline Risk-seeking (Ref: Risk 1) & & \\
\hline 2. Risk2 & $\begin{array}{c}1.415 \\
(0.366)\end{array}$ & $\begin{array}{l}0.811 \\
(0.26)\end{array}$ \\
\hline 3. Risk3 & $\begin{array}{l}1.504 \\
(0.402\end{array}$ & $\begin{array}{c}0.69 \\
(0.219)\end{array}$ \\
\hline 4. Risk4 & $\begin{array}{c}1.451 \\
(0.413)\end{array}$ & $\begin{array}{c}0.908 \\
(0.329)\end{array}$ \\
\hline 5. Risk5 & $\begin{array}{c}2.196^{* * *} \\
(0.599)\end{array}$ & $\begin{array}{c}0.378^{* * *} \\
(0.13)\end{array}$ \\
\hline 6. Risk6: high risk aversion & $\begin{array}{c}2.167^{* * *} \\
(0.556)\end{array}$ & $\begin{array}{c}0.75 \\
(0.294)\end{array}$ \\
\hline Altruistic 1 (Ref: altruistic1) & & \\
\hline 2. Altruism2 & $\begin{array}{l}0.819 \\
(0.177\end{array}$ & $\begin{array}{c}1.252 \\
(0.351)\end{array}$ \\
\hline 3. Altruism3 & $\begin{array}{c}0.846 \\
(0.186)\end{array}$ & $\begin{array}{c}0.948 \\
(0.275)\end{array}$ \\
\hline 4. Altruism4 & $\begin{array}{c}0.668 \\
(0.185)\end{array}$ & $\begin{array}{c}1.677 \\
(0.617)\end{array}$ \\
\hline
\end{tabular}


Table 2. Cont.

\begin{tabular}{|c|c|c|}
\hline & (1) & (2) \\
\hline VARIABLES & $\begin{array}{l}\text { Odds Ratio } \\
\text { Affiliation to Social Security }\end{array}$ & $\begin{array}{c}\text { Odds Ratio } \\
\text { Choosing Informality }\end{array}$ \\
\hline 5. Altruism5 & $\begin{array}{c}0.608 \\
(0.246)\end{array}$ & $\begin{array}{c}0.763 \\
(0.349)\end{array}$ \\
\hline 6. Altruism6 (individualistic) & $\begin{array}{c}0.819 \\
(0.427)\end{array}$ & $\begin{array}{l}0.250 * \\
(0.211)\end{array}$ \\
\hline Constant & $\begin{array}{c}0.0720^{* * *} \\
(0.0363)\end{array}$ & $\begin{array}{l}4.258 \text { * } \\
(3.322)\end{array}$ \\
\hline Observations & 1387 & 583 \\
\hline
\end{tabular}

Robust standard errors in parentheses. ${ }^{* * *} p<0.01,{ }^{* *} p<0.05,{ }^{*} p<0.1$.

Model 1: The second column of the table below displays the odds ratio of the logit model that explains the determinant of informality (not being insured by social security). It appears that this stratum does not have a significant effect on informality in the studied societies. However, our study confirms previous research (Bellache 2010; Sebastian and Weinschelbaum 2012; Merouani et al. 2016a) showing that education has a negative impact on informality. The analysis of marital status shows that single workers are less likely to be affiliated with social security; this may be because they do not have to care for family members or because the family insurance replaces the social security system for this category of workers. The logit model also displays the effect of employment status on the probability of being insured. It shows that permanent employees are more likely to be affiliated with social security than employers and the self-employed. The latter are risk-seeking and free-riders (Falco 2013); they tend to avoid formal institutions; hence, they avoid social insurance funds. Finally, family-contribution workers ${ }^{18}$ are less likely to be affiliated with the social security system, compared with employers and self-employed workers. This may be due to the low level of qualifications of this category of workers, and the lack of flexibility of social security systems that do not enable family workers to be entitled to social security. The results about confidence in the government do not have any significant effect on the likelihood of informality. Job satisfaction tends to be a significant determinant of informality. People who are satisfied with their job are prepared to stay, even if the job is informal. The result of the logit model shows that people who are not satisfied are less likely to be affiliated with social security. Furthermore, the household composition has a significant effect on the probability of participation in the social security system; the model shows that people who live with their parents are more likely to be enrolled. This is because the enrollment of the workers aims to cover the other members of the household. The results show also that the probability of being insured is higher for those who have insured parents. Surprisingly, gender has no effect on the probability of being insured; previous studies in Algeria have shown that females are less likely to be insured (Merouani et al. 2016a; Bellache 2010). As mentioned previously, the Sahwa dataset offers an opportunity to test the effect of some behavioral variables on social security entitlement. We tested, in particular, the effect of religion, risk aversion, and altruism on the probability of being insured. Religion does not seem to have a significant effect. However, risk aversion has a positive effect on the probability of being insured. More risk-averse people are more likely to be insured by social security. These results are in line with Merouani et al. (2016a). Altruism has no significant effect on the probability of being insured. Finally, we tested the reliability of this model (Appendix A: Table A10) and confirmed its good predictive ability ( $79 \%$ of the values were correctly predicted).

Model 2: The second model in the third column of the table above (Table 2) regresses the same variables as the first model with regard to the probability of choosing informality. The results show that the stratum does not affect significantly the probability of choosing informality. The relationship between education and the probability of choosing informality is positive. Among informal workers, the more educated are more likely to avoid the social 
security system. As mentioned in the previous section, this result may be due to the fact that less educated people are more supportive of government institutions and are therefore less rebellious with regard to social security. On the other hand, highly educated people better understand the inefficiencies of the social security system, which encourages them to avoid it. Marital status does not seem to have a significant effect on the willingness to choose informality. Another explanation of these results may be the fact that more educated people would have other savings and investments to draw on. The analysis of the job status shows that self-employed workers and employers are more likely to choose informality compared to employees (permanent and non-permanent contracts). Surprisingly, the model shows that confidence in government does not have a significant effect on the probability of choosing informality. As mentioned in the first model, job satisfaction may be one of the significant determinants of choosing informality. The second model shows that those most satisfied with their job are more likely to choose informality. This informal job may provide greater satisfaction than the satisfaction provided by social security in a formal job. We also tested the inverse relationship (effect of social security on job satisfaction, Table A9 in Appendix A); but the results were not very conclusive. We found that insured people are more likely to be satisfied with their job. We also found that people who choose informality are more likely to be satisfied with their job compared to those who do not choose informality. Otherwise, living with parents or having insured parents does not have an effect on the likelihood of choosing informality. The effect of gender and religion on the probability of choosing informality is not significant. Furthermore, using this model, we have taken note of responses to the question of seeking another job. Results show that people who choose informality are not looking for a new job, implying that they are satisfied with their job. Otherwise, risk aversion is perceived as a significant determinant of pension-saving (Bommier and Grand 2014) and social security participation (Merouani et al. 2016b); that is, we are aware of the effect of risk aversion on the probability of choosing informality in this study. Our findings are in line with previous studies, which show that the most risk-averse individuals are less likely to choose informality. Other categories of risk aversion show insignificant results. The second behavioral variable is altruism; this variable plays an important role in social dilemmas (Murphy et al. 2011; Alger and Cox 2013; Tirole 2017). This article shows that individualistic people are more likely to choose informality. This may suggest that workers do not want to participate in a system based on solidarity, where the young pay pensions for the elderly, and healthy people pay for sick people. We believe that the effect of this behavioral variable on the probability of choosing informality area value adds to the literature. Finally, the prediction ability of this model was tested (Appendix A: Table A11); $65 \%$ of the values were correctly predicted.

In order to avoid collinearity, especially between income and education, we ran another model that reveals the effect of income, sector of activity, and age on informality. This model also allows us to know in which country informality is most preferred. The results are presented in the following table (Table 3).

The table shows that income has a positive effect on the likelihood of enrollment in social security. This result is in line with the literature (Bellache 2010; Merouani et al. 2016a). Furthermore, other studies argue that the income from informal employment is lower than the income from formal employment (Shehu and Nilsson 2014). However, the effect of income on the probability of choosing informality is negative for the first three quintiles of income, and it is positive for the highest category of income. Workers in this last category are more likely to choose informality. The sector of activity analysis shows that workers in manufacturing are more likely to be enrolled in social security; the second-best-covered sector is trade and services, and the third, the building sector. The agricultural sector is the least covered by social security in the studied society. This result is in line with the data from the household employment survey. These surveys show that the coverage rate in the agriculture sector is very low (see ONS for Algeria, HCP for Morocco, and INS for Tunisia). In terms of preference for informality, the model in the last column of the table shows that workers in the construction/building sector are less likely to choose informality. This confirms Portes et al.'s 
(1989) hypothesis, where they argue that firms do not declare their employees in order to maximize their profits. Otherwise, age has a positive effect on the probability of being insured, which is in line with Shehu and Nilsson (2014) and Merouani et al. (2016a). However, age does not seem to affect the preference for informality.

Table 3. Logit models. Dependent variables: enrollment in social security and choosing informality. Source: Sahwa dataset using Stata.

\begin{tabular}{lcc}
\hline & $(\mathbf{1})$ & $(\mathbf{2})$ \\
\hline VARIABLES & $\begin{array}{c}\text { Enrollment in Social } \\
\text { Security Odds Ratio }\end{array}$ & $\begin{array}{c}\text { Choosing Informality Odds } \\
\text { Ratio }\end{array}$ \\
\hline 2. Pincome2 & $1.760^{* *}$ & $0.672^{*}$ \\
3. Pincome3 & $(0.432)$ & $(0.149)$ \\
& $4.139^{* * *}$ & $0.574^{* *}$ \\
4. Pincome4 & $(0.979$ & $(0.135$ \\
& $8.086^{* * *}$ & $1.740^{*}$ \\
2. Manufacturing & $(1.916)$ & $(0.536)$ \\
& $6.843^{* * *}$ & 0.809 \\
3. Building & $(2.628)$ & $(0.271)$ \\
& 1.358 & $0.513^{* *}$ \\
4. Trade and services & $(0.549)$ & $(0.142)$ \\
& $3.823^{* * *}$ & 1.283 \\
Age & $(1.269)$ & $(0.295)$ \\
4. Morocco & $1.173^{* * *}$ & 1.018 \\
& $(0.0283)$ & $(0.0235)$ \\
5. Tunisia & $0.288^{* * *}$ & $2.932^{* * *}$ \\
& $(0.0662)$ & $(0.7)$ \\
Constant & 0.931 & $2.059^{* * *}$ \\
& $(0.164)$ & $(0.433)$ \\
\hline Observations & $0.00120^{* * *}$ & 1 \\
Robust standard errors in parentheses & $(0.00092)$ & $(0.57)$ \\
\hline
\end{tabular}

This article reflects the context of a cross-country comparative study. The results show that the probability of being insured is higher in Algeria compared with Tunisia and Morocco. This may be due to the high share of the agriculture sector in Morocco, which is characterized by low social security coverage. Furthermore, in Tunisia, the probability of choosing informality is twice as high as the probability of choosing informality in Algeria. Indeed, the population in Tunisia might be frustrated with the traditional Tunisian political parties and their failure to resolve the problems of unemployment, poverty, and the low standard of living. This frustration led to the events of the Arab Spring, reflecting the low confidence of the population in government and institutions.

Finally, to test the robustness of our model, we ensured that the collinearity problem did not occur in our models. As mentioned in the second section, collinearity occurs when the independent variables are correlated. In the following table (Table 4), we display variation inflation factors (VIFs) to show that the collinearity problem does not exist in our models. The VIFs are all below 10 .

In order to obtain more detailed results, we tested for interaction effects in this article. As mentioned in Section 3, interaction effect analysis allows us to measure the impact of two variables simultaneously on the dependent variables, which are being an informal worker and the probability of choosing informality. In our study, we estimated the interactions between gender and education, income, employment status, country, and income quartile. These pairs have been chosen to test some of the findings in the literature. Kaliciak et al. (2019) found that highly educated females save more in voluntary pension accounts than lower-educated females in the USA; likewise, females with a high income save more than females with a low income in the USA. Females who were formerly married or 
in a relationship save less in voluntary pension accounts than other female (single/widows) in Italy. Other studies have investigated interactions between a set of socio-demographic variables and have found heterogeneous results (Adhikari and O'Leary 2013). In addition to these usual interactions, our study displays interactions between countries and gender.

Table 4. Collinearity diagnostic. Source: Sahwa dataset.

\begin{tabular}{ccccc}
\hline Variable & VIF & Squared VIF & Tolerance & R-Squared \\
\hline Urban & 1.15 & 1.07 & 0.8712 & 0.1288 \\
Education & 1.15 & 1.07 & 0.8668 & 0.1332 \\
Marital status & 1.38 & 1.17 & 0.7267 & 0.2733 \\
Job situation & 1.08 & 1.04 & 0.9252 & 0.0748 \\
Confidence in government & 1.01 & 1.01 & 0.9869 & 0.0131 \\
Job satisfaction & 1.3 & 1.14 & 0.7707 & 0.2293 \\
Living with parents & 1.4 & 1.18 & 0.7136 & 0.2864 \\
Parents insured & 1.15 & 1.07 & 0.8678 & 0.1322 \\
Gender & 1.07 & 1.04 & 0.9309 & 0.0691 \\
Religion & 1.17 & 1.08 & 0.852 & 0.148 \\
Searching for a job & 1.27 & 1.13 & 0.7894 & 0.2106 \\
Risk aversion & 1.15 & 1.07 & 0.8677 & 0.1323 \\
Altruism & 1.15 & 1.07 & 0.8712 & 0.1288 \\
Mean VIF & 1.19 & & & \\
Model 3 and 4 & & & & \\
Variable & VIF & Squared VIF & Tolerance & R-Squared \\
Pct & 1.22 & 1.1 & 0.8194 & 0.1806 \\
Sect & 1.03 & 1.01 & 0.9714 & 0.0286 \\
Age & 1.07 & 1.04 & 0.9307 & 0.0693 \\
Country & 1.15 & 1.07 & 0.8713 & 0.1287 \\
Mean VIF & 1.12 & & & \\
\hline
\end{tabular}

The results of interaction effects are presented in Table A8 of Appendix A. They confirm the positive impact of education on the probability of being insured and the probability of choosing informality, but there is no gender difference highlighted by the model; interaction between education and gender does not give a significant result.

Even if it was not significant in the previous models, marital status analysis shows that single workers are less likely to be insured than married workers; however, the interaction of marital status with gender does not show a significant difference/effect. The impact of the job situation on the dependent variables, shown in the previous models, is confirmed in this model, but its interaction with the gender variable does not show a significant effect, which means that there is no difference between men and women given their job situation. The cross-country analysis again shows that workers in Tunisia are more likely to be enrolled in social security compared to Algerian workers. However, the interaction effect shows that, compared to Algerian male workers (reference variable), Moroccan and Tunisian females are less likely to be enrolled in social security. The findings do not show a significant effect of this interaction on the likelihood of choosing informality. Furthermore, the interaction between countries and sectors of activity shows that, compared to the agriculture sector in Algeria, the services sector in Morocco, and the building and services sectors in Tunisia report a lower probability of enrollment. However, the interaction between employment status and gender does not show a significant effect on the likelihood of choosing informality. Finally, the interaction between quartiles of income and gender shows that, compared to males in the first quartile of income, females in the fourth quartile of income are more likely to choose informality. 


\section{Conclusions}

In this article, we have explored original survey data and used empirical methods to reveal the profile of workers who are excluded from the formal sector, and those who voluntarily choose informality in the studied countries. We believe that the results will enable us to formulate policy recommendations that will enhance the extension of social security to all workers in the studied countries.

We have demonstrated that more educated workers are more likely to be insured, but among informal workers, the more educated are more likely to choose informality. The social security system and insurance companies must provide strong incentives to this category of workers (Thaler 2016) because they are in a position to make a responsible choice. Insurance contracts must be fair enough to attract highly educated workers. We have also shown that self-employed workers are more likely to choose informality, due to the distortion of the insurance system provided for self-employed people in these countries. The self-employed schemes need to develop their insurance contracts and offer the same benefits to the self-employed as to employees. Currently, the self-employed are excluded from some benefits such as support for accidents at work and maternity leave. Allowing access to these benefits will increase the participation of the self-employed in the social security system. Some authors (Renana 1998) have recommended improving social security coverage through market and insurance companies. These companies would be more likely to offer a contract suitable to the income and needs of self-employed workers. The results show that workers may prefer informal employment because it offers higher job satisfaction than formal employment. Risk aversion seems to be a significant determinant of social security participation; hence, social security systems may offer a high quality of protection in order to attract more adherents. The results of studies on altruism show that individualistic workers are more likely to choose informality. This category of workers (individualistic people) may prefer to save funds in their individual accounts rather than saving in a pay-as-you-go system that is based on solidarity.

Our next general conclusion states that certain categories of workers are excluded from the formal labor market, and that they need special assistance through the Beveridgian component of the social protection system. According to the result of our models, these categories are contributing family workers, non-permanent employees, women, single people, poorly educated workers, workers with a low income, and workers in the building sector.

Moving now onto more specific findings, according to the results of the interaction effect, Moroccan workers, particularly women with high incomes, are more likely to choose informality; therefore, they may be targeted with specific incentives to participate in the formal sector. This can be carried out through the existing systems of social security or through a market that offers more suitable insurance contracts to wealthy female workers. Women in Morocco and Tunisia are less likely to be covered by social security than in Algeria, which may push policymakers to think about implementing particular measures in order to provide coverage for these categories of workers. The results also show that, compared to the Algerian system, the Moroccan and Tunisian systems are less likely to cover workers in the building trade and services sectors. There is an opportunity here for these countries to focus on those sectors.

Finally, we should note that this area of study is in need of further research. We have focused here only on three Maghreb countries, while the approach can be extended to two more Arabic countries (Egypt and Lebanon) for which data are available. Additionally, we can include some macroeconomic predictors such as GDP per capita in each country to explain the informality. Thus far, the study was an attempt to attribute the low social security coverage to low state effectiveness and legitimacy, but we aim to develop the analysis further regarding the relationship between informality, social security coverage, and the social realm of state governance and how it manages to offer protection from social grievances. While there is agreement on the conceptual and empirical relationship between state fragility, grievance, and conflict (Kivimäki 2021), this article should be followed up by a study empirically explaining those relationships in the Maghreb and Arab countries. It 
should show how social protection coverage could be explained by state legitimacy and effectiveness, and its potential to attract more workers. Understanding the aforementioned relationships has tremendous significance for the future shape of social security systems and the achievement of sustainable development goals (SDG 8) in the workplace.

Author Contributions: Conceptualization, W.M.; methodology, W.M. and C.E.M.; software, W.M.; validation, W.M. and N.E.H.; formal analysis, W.M.; investigation, W.M.; resources, W.M.; data curation, W.M.; writing—original draft preparation, W.M.; writing—review and editing, W.M.; visualization, W.M.; supervision, W.M. and N.E.H.; funding acquisition, N.E.H. All authors have read and agreed to the published version of the manuscript.

Funding: The SAHWA survey received funding from the European Community's Seventh Framework Program FP7 /2007-2013 under Convention No. 613174 for the SAHWA project (www.sahwa.eu, accessed on 30 June 2021).

Informed Consent Statement: Informed consent was obtained from all subjects involved in the study.

Acknowledgments: We are thankful to Atif Kubursi, Timo Kivimäki, and Rana Jawad as well as to the two anonymous referees of Social Sciences for their constructive remarks on the earlier version of this manuscript. We would also like to acknowledge the participants of the 24th ERF Annual Conference (Cairo, 2018) for their encouragement. All remaining errors are our own.

Conflicts of Interest: The authors declare no conflict of interest.

\section{Appendix A. Summary Statistics}

Table A1. Affiliation to social security and the reasons for not being insured. Source: Sahwa dataset.

\begin{tabular}{|c|c|c|c|c|c|c|c|}
\hline \multicolumn{4}{|c|}{ Affiliation to social security } & \multicolumn{4}{|c|}{ Choose informality } \\
\hline No & 1039 & 68.13 & 68.13 & No & 280 & 31.11 & 31.11 \\
\hline Yes & 486 & 31.87 & 100 & Yes & 620 & 68.89 & 100 \\
\hline Total & 1525 & 100 & & Total & 900 & 100 & \\
\hline \multicolumn{3}{|c|}{ Affiliation to social security.dz } & \multicolumn{5}{|c|}{ Choose informality.dz } \\
\hline No & 326 & 58.74 & 58.74 & Non & 112 & 43.75 & 43.75 \\
\hline Yes & 229 & 41.26 & 100 & Oui & 144 & 56.25 & 100 \\
\hline Total & 555 & 100 & & Total & 256 & 100 & \\
\hline \multicolumn{3}{|c|}{ Affiliation to social security.ma } & \multicolumn{5}{|c|}{ Choose informality.ma } \\
\hline No & 354 & 78.15 & 78.15 & Non & 81 & 23.01 & 23.01 \\
\hline Yes & 99 & 21.85 & 100 & Oui & 271 & 76.99 & 100 \\
\hline Total & 453 & 100 & & Total & 352 & 100 & \\
\hline \multicolumn{3}{|c|}{ Affiliation to social security.tn } & \multicolumn{5}{|c|}{ Choose informality.tn } \\
\hline No & 359 & 69.44 & 69.44 & Non & 87 & 29.79 & 29.79 \\
\hline Yes & 158 & 30.56 & 100 & Oui & 205 & 70.21 & 100 \\
\hline Total & 517 & 100 & & Total & 292 & 100 & \\
\hline
\end{tabular}

Table A2. Affiliation to social security and the reason for not being insured according to marital status. Source: Sahwa dataset.

\begin{tabular}{|c|c|c|c|c|c|c|c|}
\hline \multicolumn{3}{|c|}{ Affiliation to social security } & \multicolumn{4}{|c|}{ Choose informality } & \multirow[b]{2}{*}{ Tota } \\
\hline & No & Yes & Total & & No & Yes & \\
\hline Married & 112 & 80 & 192 & Married & 26 & 74 & 100 \\
\hline Single & 911 & 401 & 1312 & Single & 252 & 532 & 784 \\
\hline Total & 1023 & 481 & 1504 & Total & 278 & 606 & 884 \\
\hline \multicolumn{3}{|c|}{ Affiliation to social security.dz } & \multicolumn{5}{|c|}{ Choose informality.dz } \\
\hline & No & Yes & Total & & No & Yes & Total \\
\hline Married & 25 & 26 & 51 & Married & 5 & 14 & 19 \\
\hline Single & 299 & 203 & 502 & Single & 106 & 129 & 235 \\
\hline Total & 324 & 229 & 553 & Total & 111 & 143 & 254 \\
\hline
\end{tabular}


Table A2. Cont.

\begin{tabular}{|c|c|c|c|c|c|c|c|}
\hline \multicolumn{3}{|c|}{ Affiliation to social security.ma } & \multicolumn{5}{|c|}{ Choose informality.ma } \\
\hline & No & Yes & Total & & No & Yes & Total \\
\hline Married & 57 & 22 & 79 & Married & 15 & 41 & 56 \\
\hline Single & 285 & 72 & 357 & Single & 65 & 219 & 284 \\
\hline Total & 342 & 94 & 436 & Total & 80 & 260 & 340 \\
\hline \multicolumn{3}{|c|}{ Affiliation to social security.tn } & \multicolumn{5}{|c|}{ Choose informality.tn } \\
\hline & No & Yes & Total & & No & Yes & Total \\
\hline Married & 30 & 32 & 62 & Married & 6 & 19 & 25 \\
\hline Single & 327 & 126 & 453 & Single & 81 & 184 & 265 \\
\hline Total & 357 & 158 & 515 & Total & 87 & 203 & 290 \\
\hline
\end{tabular}

Table A3. Affiliation to social security and the reason for not being insured according to level of education. Source:

Sahwa dataset.

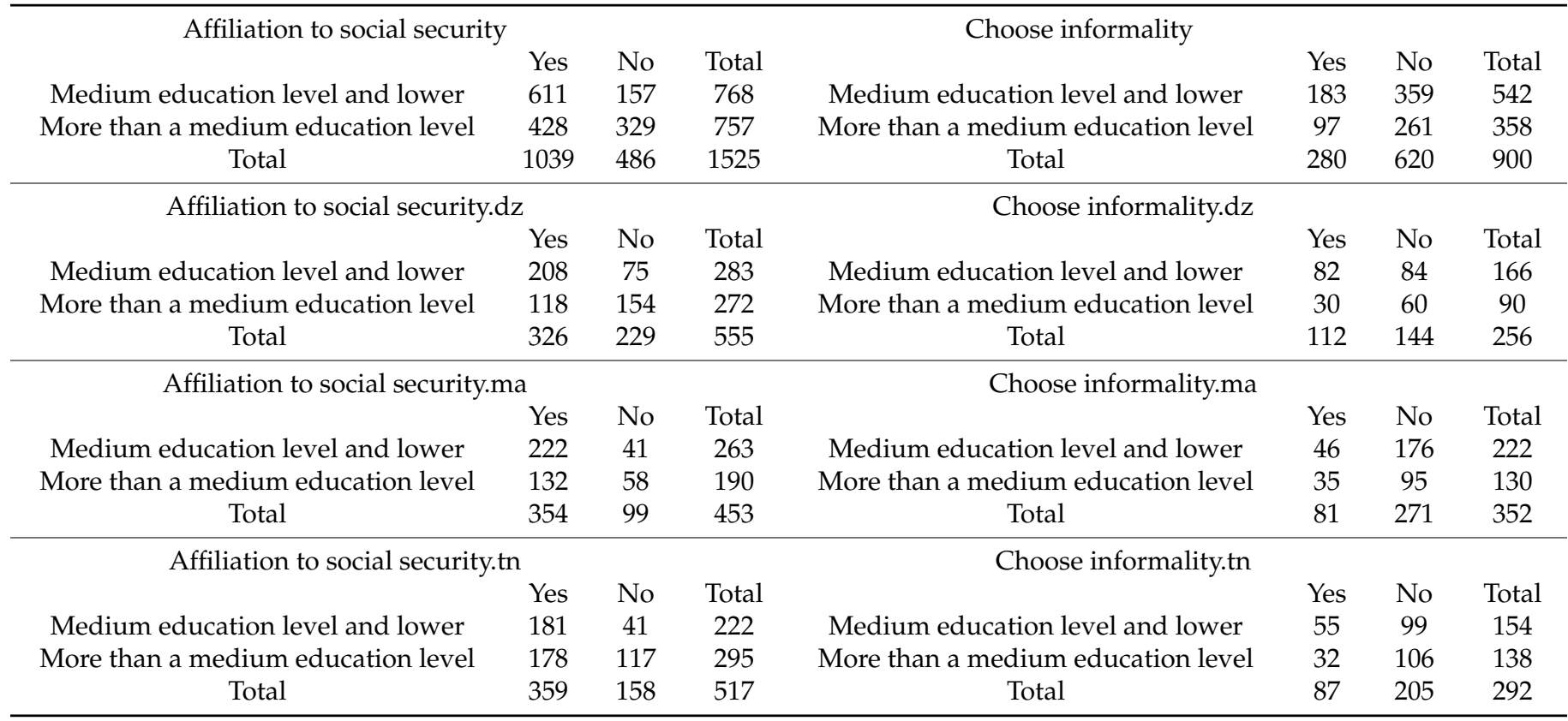

Table A4. Affiliation to social security and the reason for not being insured, according to confidence in government. Source:

Sahwa dataset.

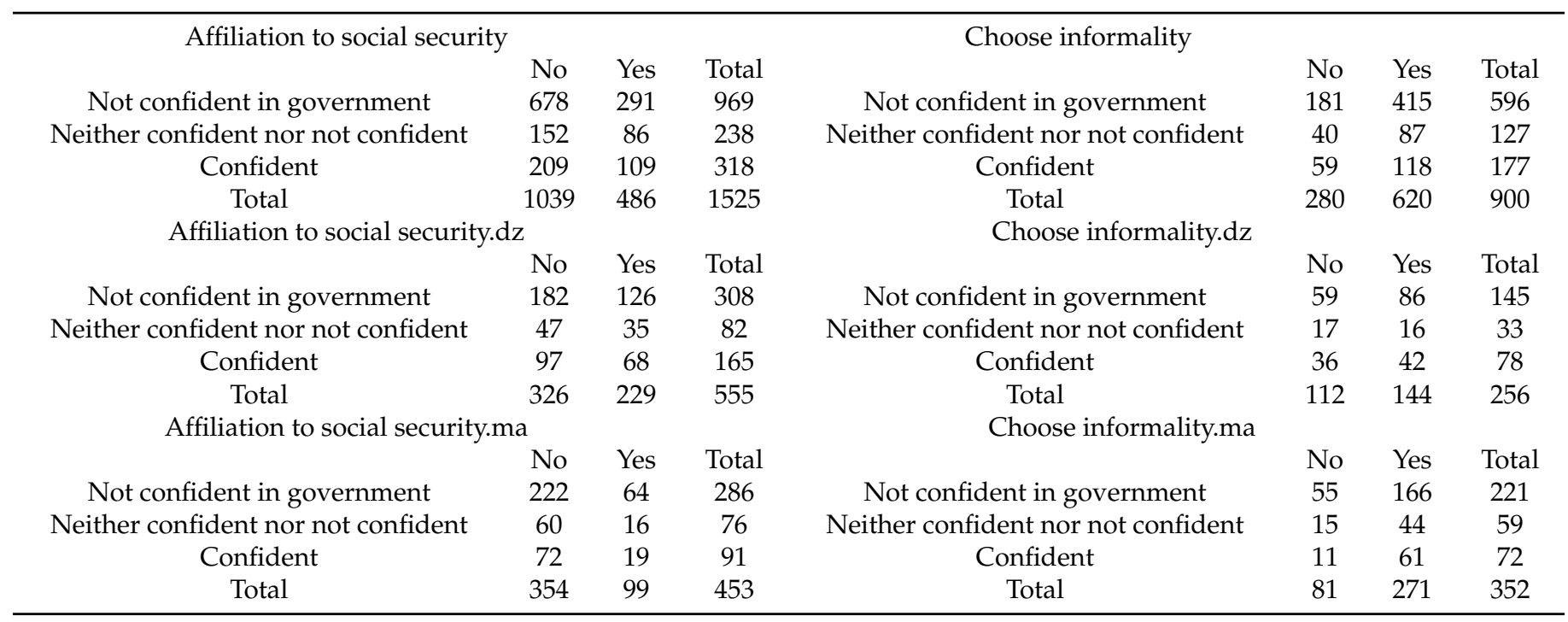


Table A4. Cont.

\begin{tabular}{|c|c|c|c|c|c|c|c|}
\hline \multicolumn{3}{|c|}{ Affiliation to social security.tn } & \multicolumn{5}{|c|}{ Choose informality.tn } \\
\hline & No & Yes & Total & & No & Yes & Total \\
\hline Not confident in government & 274 & 101 & 375 & Not confident in government & 67 & 163 & 230 \\
\hline Neither confident nor not confident & 45 & 35 & 80 & Neither confident nor not confident & 8 & 27 & 35 \\
\hline Confident & 40 & 22 & 62 & Confident & 12 & 15 & 27 \\
\hline Total & 359 & 158 & 517 & Total & 87 & 205 & 292 \\
\hline
\end{tabular}

Table A5. Affiliation to social security and the reason for not being insured according to the sector of activity. Source: Sahwa dataset.

\begin{tabular}{|c|c|c|c|c|c|c|c|}
\hline \multicolumn{3}{|c|}{ Affiliation to social security } & \multicolumn{4}{|c|}{ Choose informality } & \multirow[b]{2}{*}{ Total } \\
\hline & Non & Yes & Total & & Non & Yes & \\
\hline Agriculture & 174 & 26 & 200 & Agriculture & 50 & 106 & 156 \\
\hline Industry & 98 & 94 & 192 & Industry & 32 & 54 & 86 \\
\hline Building & 154 & 31 & 185 & Building & 63 & 70 & 133 \\
\hline Services & 613 & 335 & 948 & Services & 135 & 390 & 525 \\
\hline Total & 1039 & 486 & 1525 & Total & 280 & 620 & 900 \\
\hline \multicolumn{3}{|c|}{ Affiliation to social security.dz } & \multicolumn{5}{|c|}{ Choose informality.dz } \\
\hline & Non & Yes & Total & & Non & Yes & Total \\
\hline Agriculture & 58 & 6 & 64 & Agriculture & 28 & 22 & 50 \\
\hline Industry & 27 & 23 & 50 & Industry & 9 & 16 & 25 \\
\hline Building & 66 & 19 & 85 & Building & 36 & 23 & 59 \\
\hline Services & 175 & 181 & 356 & Services & 39 & 83 & 122 \\
\hline Total & 326 & 229 & 555 & Total & 112 & 144 & 256 \\
\hline \multicolumn{3}{|c|}{ Affiliation to social security.ma } & \multicolumn{5}{|c|}{ Choose informality.ma } \\
\hline & Non & Yes & Total & & Non & Yes & Total \\
\hline Agriculture & 62 & 12 & 74 & Agriculture & 10 & 52 & 62 \\
\hline Industry & 21 & 14 & 35 & Industry & 5 & 16 & 21 \\
\hline Building & 24 & 2 & 26 & Building & 8 & 16 & 24 \\
\hline Services & 247 & 71 & 318 & Services & 58 & 187 & 245 \\
\hline Total & 354 & 99 & 453 & Total & 81 & 271 & 352 \\
\hline \multicolumn{3}{|c|}{ Affiliation to social security.tn } & \multicolumn{5}{|c|}{ Choose informality.tn } \\
\hline & Non & Yes & Total & & Non & Yes & Total \\
\hline Agriculture & 54 & 8 & 62 & Agriculture & 12 & 32 & 44 \\
\hline Industry & 50 & 57 & 107 & Industry & 18 & 22 & 40 \\
\hline Building & 64 & 10 & 74 & Building & 19 & 31 & 50 \\
\hline Services & 191 & 83 & 274 & Services & 38 & 120 & 158 \\
\hline Total & 359 & 158 & 517 & Total & 87 & 205 & 292 \\
\hline
\end{tabular}

Table A6. Affiliation to social security and the reason for not being insured among new job seekers. Source: Sahwa dataset.

\begin{tabular}{|c|c|c|c|c|c|c|c|}
\hline \multicolumn{3}{|c|}{ Affiliation to social security } & \multicolumn{4}{|c|}{ Choose informality } & \multirow[b]{2}{*}{ Total } \\
\hline & No & Yes & Total & & No & Yes & \\
\hline Yes (searching for job) & 477 & 129 & 606 & Yes (searching for job) & 161 & 237 & 398 \\
\hline No & 562 & 357 & 919 & No & 119 & 383 & 502 \\
\hline Total & 1039 & 486 & 1525 & Total & 280 & 620 & 900 \\
\hline \multicolumn{3}{|c|}{ Affiliation to social security.dz } & \multicolumn{5}{|c|}{ Choose informality.dz } \\
\hline & No & Yes & Total & & No & Yes & Total \\
\hline Yes (search for job) & 198 & 60 & 258 & Yes (search for job) & 82 & 76 & 158 \\
\hline No & 128 & 169 & 297 & No & 30 & 68 & 98 \\
\hline Total & 326 & 229 & 555 & Total & 112 & 144 & 256 \\
\hline \multicolumn{3}{|c|}{ Affiliation to social security.ma } & \multicolumn{5}{|c|}{ Choose informality.ma } \\
\hline & No & Yes & Total & & No & Yes & Total \\
\hline Yes (searching for job) & 92 & 24 & 116 & Yes (searching for job) & 26 & 65 & 91 \\
\hline $\mathrm{No}$ & 262 & 75 & 337 & No & 55 & 206 & 261 \\
\hline Total & 354 & 99 & 453 & Total & 81 & 271 & 352 \\
\hline
\end{tabular}


Table A6. Cont.

\begin{tabular}{cccccccc}
\hline \multicolumn{2}{c}{ Affiliation to social security.tn } & \multicolumn{2}{c}{ Choose informality.tn } & \multicolumn{2}{c}{ No } & Yes & Total \\
& No & Yes & Total & Yes (searching for job) & 53 & 96 \\
Yes (searching for job) & 187 & 45 & 232 & No & 34 & 109 \\
No & 172 & 113 & 285 & Total & 87 & 205 & 292 \\
Total & 359 & 158 & 517 & & 84 \\
\hline
\end{tabular}

Table A7. Affiliation to social security and the reason for not being insured according to job satisfaction. Source: Sahwa dataset.

\begin{tabular}{|c|c|c|c|c|c|c|c|}
\hline \multicolumn{3}{|c|}{ Affiliation to social security } & \multicolumn{4}{|c|}{ Choose informality } & \multirow[b]{2}{*}{ Total } \\
\hline & No & Yes & Total & & No & Yes & \\
\hline Very satisfied & 166 & 161 & 327 & Very satisfied & 24 & 128 & 152 \\
\hline Satisfied & 413 & 232 & 645 & Satisfied & 104 & 259 & 363 \\
\hline Dissatisfied & 272 & 66 & 338 & Dissatisfied & 83 & 142 & 225 \\
\hline Very dissatisfied & 188 & 27 & 215 & Very dissatisfied & 69 & 91 & 160 \\
\hline Total & 1039 & 486 & 1525 & Total & 280 & 620 & 900 \\
\hline \multicolumn{3}{|c|}{ Affiliation to social security.dz } & \multicolumn{5}{|c|}{ Choose informality.dz } \\
\hline & No & Yes & Total & & No & Yes & Total \\
\hline Very satisfied & 38 & 75 & 113 & Very satisfied & 6 & 27 & 33 \\
\hline Satisfied & 106 & 113 & 219 & Satisfied & 32 & 49 & 81 \\
\hline Dissatisfied & 128 & 34 & 162 & Dissatisfied & 51 & 47 & 98 \\
\hline Very dissatisfied & 54 & 7 & 61 & Very dissatisfied & 23 & 21 & 44 \\
\hline Total & 326 & 229 & 555 & Total & 112 & 144 & 256 \\
\hline \multicolumn{3}{|c|}{ Affiliation to social security.ma } & \multicolumn{5}{|c|}{ Choose informality.ma } \\
\hline & No & Yes & Total & & No & Yes & Total \\
\hline Very satisfied & 59 & 36 & 95 & Very satisfied & 5 & 54 & 59 \\
\hline Satisfied & 189 & 53 & 242 & Satisfied & 48 & 140 & 188 \\
\hline Dissatisfied & 74 & 5 & 79 & Dissatisfied & 17 & 57 & 74 \\
\hline Very dissatisfied & 32 & 5 & 37 & Very dissatisfied & 11 & 20 & 31 \\
\hline Total & 354 & 99 & 453 & Total & 81 & 271 & 352 \\
\hline \multicolumn{3}{|c|}{ Affiliation to social security.tn } & \multicolumn{5}{|c|}{ Choose informality.tn } \\
\hline & No & Yes & Total & & No & Yes & Total \\
\hline Very satisfied & 69 & 50 & 119 & Very satisfied & 13 & 47 & 60 \\
\hline Satisfied & 118 & 66 & 184 & Satisfied & 24 & 70 & 94 \\
\hline Dissatisfied & 70 & 27 & 97 & Dissatisfied & 15 & 38 & 53 \\
\hline Very dissatisfied & 102 & 15 & 117 & Very dissatisfied & 35 & 50 & 85 \\
\hline Total & 359 & 158 & 517 & Total & 87 & 205 & 292 \\
\hline
\end{tabular}

Table A8. Logit model with interaction effects. Dependent variables: being insured (second column) and choosing informality (third column). Source: Sahwa dataset.

(1)

\begin{tabular}{lcc}
\hline VARIABLES & Odds Ratio & Odds Ratio \\
\hline 2. Female & 2.301 & $0.0650^{* *}$ \\
& $(1.719)$ & $(0.0778)$ \\
1. More than medium education level & $2.116^{* * *}$ & $1.628^{*}$ \\
& $(0.427)$ & $(0.409)$ \\
2. Female \#1. More than medium education level & 1.434 & 1.476 \\
& $(0.599)$ & $(0.799)$ \\
1. Single & $0.302 * * *$ & 0.598 \\
& $(0.116)$ & $(0.296)$ \\
1. Single \#2. Female & 2.052 & 2.204 \\
& $(1.471)$ & $(1.969)$ \\
2. Permanent employees & $8.641 * * *$ & $0.324 * *$ \\
& $(2.371)$ & $(0.145)$ \\
3. Non(permanent employees & 0.805 & $0.328^{* * *}$ \\
\end{tabular}


Table A8. Cont.

\begin{tabular}{|c|c|c|}
\hline & (1) & (3) \\
\hline VARIABLES & Odds Ratio & Odds Ratio \\
\hline \multirow[t]{2}{*}{ 4. Family workers } & 0.360 * & 1 \\
\hline & $(0.215)$ & 0 \\
\hline \multirow[t]{2}{*}{ 2. Permanent employees \#2. Female } & 0.687 & 0.913 \\
\hline & $(0.419)$ & $(0.85)$ \\
\hline \multirow[t]{2}{*}{ 3. Non (permanent) employees \#2. Female } & 1.54 & 1.738 \\
\hline & $(0.866)$ & $(1.34)$ \\
\hline \multirow[t]{2}{*}{ 4. Family workers \#2. Female } & 2.063 & 1 \\
\hline & $(1.907)$ & 0 \\
\hline \multirow[t]{2}{*}{ 1. Living with parents } & 1.716 & 0.762 \\
\hline & $(0.629)$ & $(0.276)$ \\
\hline \multirow[t]{2}{*}{ 2. Female \#1. Living with parents } & 0.497 & 0.922 \\
\hline & $(0.339)$ & $(0.657)$ \\
\hline \multirow{2}{*}{ 4. Morocco } & 3.867 & $3.716^{*}$ \\
\hline & $(3.561)$ & $(2.57)$ \\
\hline \multirow[t]{2}{*}{ 5.Tunisia } & $7.628^{* * *}$ & 1.955 \\
\hline & $(5.352)$ & $(1.264)$ \\
\hline \multirow[t]{2}{*}{ 4. Morocco \#2. Female } & $0.229 * *$ & 2.418 \\
\hline & $(0.156)$ & $(2.231)$ \\
\hline \multirow[t]{2}{*}{ 5. Tunisia \#2. Female } & $0.461 *$ & 1.906 \\
\hline & $(0.206)$ & $(1.739)$ \\
\hline \multirow[t]{2}{*}{ 2. Industry } & $3.783^{* *}$ & 1.55 \\
\hline & $(2.17)$ & $(1.128)$ \\
\hline \multirow{2}{*}{ 3. Building } & $4.409^{* * *}$ & 0.69 \\
\hline & $(2.358)$ & $(0.409)$ \\
\hline \multirow[t]{2}{*}{ 4. Services } & $6.977^{* * *}$ & 1.813 \\
\hline & $(3.308)$ & $(1.017)$ \\
\hline \multirow[t]{2}{*}{ 4. Morocco \#2. Industry } & 0.127 & 2.88 \\
\hline & $(0.167)$ & $(4.182)$ \\
\hline \multirow[t]{2}{*}{ 4. Morocco \#3. Building } & 0.138 & 1.179 \\
\hline & $(0.217)$ & $(1.2)$ \\
\hline \multirow[t]{2}{*}{ 4. Morocco \#4. Services } & $0.0631^{* * *}$ & 0.48 \\
\hline & $(0.0574)$ & $(0.37)$ \\
\hline \multirow[t]{2}{*}{ 5. Tunisia \#2. Industry } & 0.472 & 0.612 \\
\hline & $(0.394)$ & $(0.559)$ \\
\hline \multirow[t]{2}{*}{ 5. Tunisia \#3. Building } & $0.0986^{* * *}$ & 1.372 \\
\hline & $(0.0832)$ & (1.095) \\
\hline \multirow[t]{2}{*}{ 5. Tunisia \#4. Services } & $0.0894^{* * *}$ & 0.895 \\
\hline & $(0.0677)$ & $(0.654)$ \\
\hline \multirow[t]{2}{*}{ 2. Second quartile of income } & $2.131 *$ & $0.519^{* *}$ \\
\hline & $(0.836)$ & $(0.154)$ \\
\hline 3. Third quartile of income & $5.435^{* * *}$ & $0.427^{* * *}$ \\
\hline & $(1.918)$ & $(0.135)$ \\
\hline 4. Fourth quartile of income & $10.66^{* * *}$ & 0.583 \\
\hline & $(3.809)$ & $(0.242)$ \\
\hline 2. Second quartile of income \#2.Female & 1.114 & 1.921 \\
\hline & $(0.616)$ & $(1.057)$ \\
\hline 3. Third quartile of income \#2.Female & 0.914 & 3.665 \\
\hline & $(0.557)$ & $(4.182)$ \\
\hline 4. Fourth quartile of income \#2. Female & 0.585 & $16.26^{* *}$ \\
\hline & $(0.357)$ & $(21.6)$ \\
\hline Constant & $0.0185^{* * *}$ & $4.618^{* *}$ \\
\hline & $(0.0124)$ & $(3.355)$ \\
\hline Observations & 1202 & 509 \\
\hline
\end{tabular}

Robust standard errors in parentheses. ${ }^{* * *} p<0.01,{ }^{* *} p<0.05,{ }^{*} p<0.1$. 
Table A9. Ordered logit model; the dependent variable is job satisfaction. Ordered form very satisfied to not at all satisfied. Source: Sahwa survey and Stata software.

\begin{tabular}{|c|c|c|}
\hline & (Odds Ratio) & (Odds Ratio2) \\
\hline VARIABLES & Job Satisfaction & Job Satisfaction \\
\hline Affiliation to social security & $\begin{array}{l}0.543^{* * *} \\
(0.0708)\end{array}$ & \\
\hline Looking for a new job & $\begin{array}{l}0.180^{* * *} \\
(0.0235)\end{array}$ & $\begin{array}{l}0.171^{* * *} \\
(0.0291)\end{array}$ \\
\hline Urban & $\begin{array}{l}0.723^{* * *} \\
(0.0841)\end{array}$ & $\begin{array}{l}0.649 * * * \\
(0.0955)\end{array}$ \\
\hline Female & $\begin{array}{c}1.084 \\
(0.142)\end{array}$ & $\begin{array}{c}0.91 \\
(0.167)\end{array}$ \\
\hline 2. Permanent employees & $\begin{array}{c}1.327^{*} \\
(0.22)\end{array}$ & $\begin{array}{c}1.241 \\
(0.321)\end{array}$ \\
\hline 3. Non(permanent employees & $\begin{array}{c}2.133^{* * *} \\
(0.308)\end{array}$ & $\begin{array}{c}1.851^{* * *} \\
(0.35)\end{array}$ \\
\hline 4. Family workers & $\begin{array}{l}1.916^{* *} \\
(0.536)\end{array}$ & $\begin{array}{l}1.789 * \\
(0.588)\end{array}$ \\
\hline Single & $\begin{array}{l}1.493^{* *} \\
(0.257)\end{array}$ & $\begin{array}{c}1.877^{* * * *} \\
(0.443)\end{array}$ \\
\hline 1. More than medium education level & $\begin{array}{c}0.883 \\
(0.101)\end{array}$ & $\begin{array}{c}0.97 \\
(0.144)\end{array}$ \\
\hline 2.Risk 2 & $\begin{array}{l}1.008 \\
(0.187)\end{array}$ & $\begin{array}{c}1.194 \\
(0.275)\end{array}$ \\
\hline 3. Risk 3 & $\begin{array}{c}1.189 \\
(0.213)\end{array}$ & $\begin{array}{c}1.266 \\
(0.297)\end{array}$ \\
\hline 4. Risk 4 & $\begin{array}{c}1.361 \\
(0.282)\end{array}$ & $\begin{array}{c}1.305 \\
(0.332)\end{array}$ \\
\hline 5. Risk 5 & $\begin{array}{c}0.913 \\
(0.179)\end{array}$ & $\begin{array}{c}0.67 \\
(0.198)\end{array}$ \\
\hline 6. Risk 6 & $\begin{array}{c}1.012 \\
(0.223)\end{array}$ & $\begin{array}{c}0.855 \\
(0.278)\end{array}$ \\
\hline 2. Altruism 2 & $\begin{array}{c}0.984 \\
(0.145)\end{array}$ & $\begin{array}{c}0.717 \\
(0.146)\end{array}$ \\
\hline 3. Altruism 3 & $\begin{array}{c}1.076 \\
(0.173)\end{array}$ & $\begin{array}{c}0.898 \\
(0.2)\end{array}$ \\
\hline 4. Altruism 4 & $\begin{array}{c}1.286 \\
(0.271)\end{array}$ & $\begin{array}{l}1.138 \\
(0.309)\end{array}$ \\
\hline 5. Altruism 5 & $\begin{array}{c}0.855 \\
(0.234)\end{array}$ & $\begin{array}{c}1.198 \\
(0.474)\end{array}$ \\
\hline 6. Altruism 6 & $\begin{array}{c}0.673 \\
(0.322)\end{array}$ & $\begin{array}{c}0.579 \\
(0.426)\end{array}$ \\
\hline 7. Altruism 719 & $\begin{array}{c}0.506^{* * *} \\
(0.131)\end{array}$ & \\
\hline Choose informality & & $\begin{array}{c}0.684^{* *} \\
(0.117)\end{array}$ \\
\hline Constant cut 1 & $\begin{array}{l}0.0214^{* * *} \\
(0.00815)\end{array}$ & $\begin{array}{l}0.0126^{* * *} \\
(0.00638)\end{array}$ \\
\hline Constant cut 2 & $\begin{array}{l}0.237^{* * *} \\
(0.0854)\end{array}$ & $\begin{array}{l}0.127^{* * *} \\
(0.0601)\end{array}$ \\
\hline Constant cut 3 & $\begin{array}{c}1.128 \\
(0.396)\end{array}$ & $\begin{array}{c}0.602 \\
(0.272)\end{array}$ \\
\hline Observations & 1388 & 798 \\
\hline
\end{tabular}

Robust standard errors in parentheses. ${ }^{* * *} p<0.01,{ }^{* *} p<0.05,{ }^{*} p<0.1$. 
Table A10. Test of reliability of the logit model in Table 2 (dependent variable: informal employment).

\begin{tabular}{ccc}
\hline Classified + if Predicted $\operatorname{Pr}(\mathbf{D})$ & $\geq \mathbf{0 . 5}$ & \\
\hline \multicolumn{4}{c}{ True D defined as aff $\mathbf{~} \mathbf{= 0}$} \\
\hline Sensitivity & $\operatorname{Pr}(+\mathrm{D})$ & $57.84 \%$ \\
Specificity & $\operatorname{Pr}(-\sim \mathrm{D})$ & $90.07 \%$ \\
Positive predictive value & $\operatorname{Pr}(\mathrm{D}+)$ & $75.00 \%$ \\
Negative predictive value & $\operatorname{Pr}(\sim \mathrm{D}-)$ & $80.57 \%$ \\
\hline False + rate for true $\sim \mathrm{D}$ & $\operatorname{Pr}(+\sim \mathrm{D})$ & $9.93 \%$ \\
False - rate for true D & $\operatorname{Pr}(-\mathrm{D})$ & $42.16 \%$ \\
False + rate for classified + & $\operatorname{Pr}(\sim \mathrm{D}+)$ & $25.00 \%$ \\
False - rate for classified - & $\operatorname{Pr}(\mathrm{D}-)$ & $19.43 \%$ \\
\hline Correctly classified & \\
\hline
\end{tabular}

Table A11. Test of reliability of the logit model in Table 2 (dependent variable: choosing informality).

\begin{tabular}{ccc}
\hline & True D Defined as Choice $!=\mathbf{0}$ \\
\hline Sensitivity & $\operatorname{Pr}(+\mathrm{D})$ & \\
Specificity & $\operatorname{Pr}(-\sim \mathrm{D})$ & $75.68 \%$ \\
Positive predictive value & $\operatorname{Pr}(\mathrm{D}+)$ & $50.39 \%$ \\
Negative predictive value & $\operatorname{Pr}(\sim \mathrm{D}-)$ & $66.40 \%$ \\
\hline False + rate for true $\sim \mathrm{D}$ & $\operatorname{Pr}(+\sim \mathrm{D})$ & $61.54 \%$ \\
False - rate for true D & $\operatorname{Pr}(-\mathrm{D})$ & $49.61 \%$ \\
False + rate for classified + & $\operatorname{Pr}(\sim \mathrm{D}+)$ & $24.32 \%$ \\
False - rate for classified - & $\operatorname{Pr}(\mathrm{D}-)$ & $33.60 \%$ \\
\hline \multicolumn{2}{c}{ Correctly classified } & $38.46 \%$ \\
\hline
\end{tabular}

Table A12. Variables description.

\begin{tabular}{|c|c|}
\hline Variables of the Models & Definition/Description \\
\hline Urban & Dummy variable equal to 1 if the respondent lives in urban area \\
\hline & More than secondary education \\
\hline \multicolumn{2}{|r|}{ Dummy variable equal to 1 if the respondent has more than secondary education } \\
\hline \multicolumn{2}{|r|}{ Single } \\
\hline Employment Status & $\begin{array}{l}\text { Employment status variables have } 4 \text { alternatives: } 1 \text { - } \text { self-employed reference variable in the } \\
\text { models, } 2 \text {-permanent employee, } 3 \text {-non-permanent employee, } 4 \text { - contributing family help } \\
\text { Confidence in government is an ordinal variable presented as a Likert scale; } 0 \text { means no }\end{array}$ \\
\hline $\begin{array}{l}\text { Confidence in } \\
\text { government }\end{array}$ & $\begin{array}{l}\text { confidence at all in government and } 10 \text { means absolute confidence in it. This variable has been } \\
\text { re-codified into } 3 \text { categories (1-not confident, } 2 \text {-neither confident nor } \\
\text { not confident, } 3 \text { - confident })\end{array}$ \\
\hline Job satisfaction & $\begin{array}{l}\text { Job satisfaction variable is an ordinal variable classifying respondents from } 1 \text { (those who are very } \\
\text { satisfied with their job) to } 5 \text { (very dissatisfied) }\end{array}$ \\
\hline Living with parents & Dummy variable equal to 1 if the respondent reports that he/she lives with parents \\
\hline Parents insured & Dummy variable equal to 1 if parents of respondents are insured by social security \\
\hline Female & Dummy variable equal to 1 if the respondent is a female \\
\hline Importance of religion at work & $\begin{array}{l}\text { Religious variable is an ordinal variable presented as a Likert scale, ranging from } 1 \text { if the } \\
\text { respondent declares that religion is very important to } 5 \text { if religions is not important at all }\end{array}$ \\
\hline $\begin{array}{l}\text { Importance of religion in } \\
\text { commercial transaction }\end{array}$ & $\begin{array}{l}\text { Religious variable is an ordinal variable presented a Likert scale, ranging from } 1 \text { if the respondent } \\
\text { declares that religion is very important to } 5 \text { if religions is not important at all }\end{array}$ \\
\hline Not looking for a new job & Dummy variable equal to 1 if the respondent is not looking for a new job \\
\hline Risk aversion & $\begin{array}{l}\text { Risk aversion variable is an ordinal variable classifying individuals in the Likert scale, ranging } \\
\text { from } 1 \text { (risk-tolerant) to } 6 \text { (risk-averse) }\end{array}$ \\
\hline Altruism & $\begin{array}{c}\text { Altruism variable is an ordinal variable classifying respondents from } 1 \text { (most altruistic) to } 6 \\
\text { (most individualistic) }\end{array}$ \\
\hline
\end{tabular}



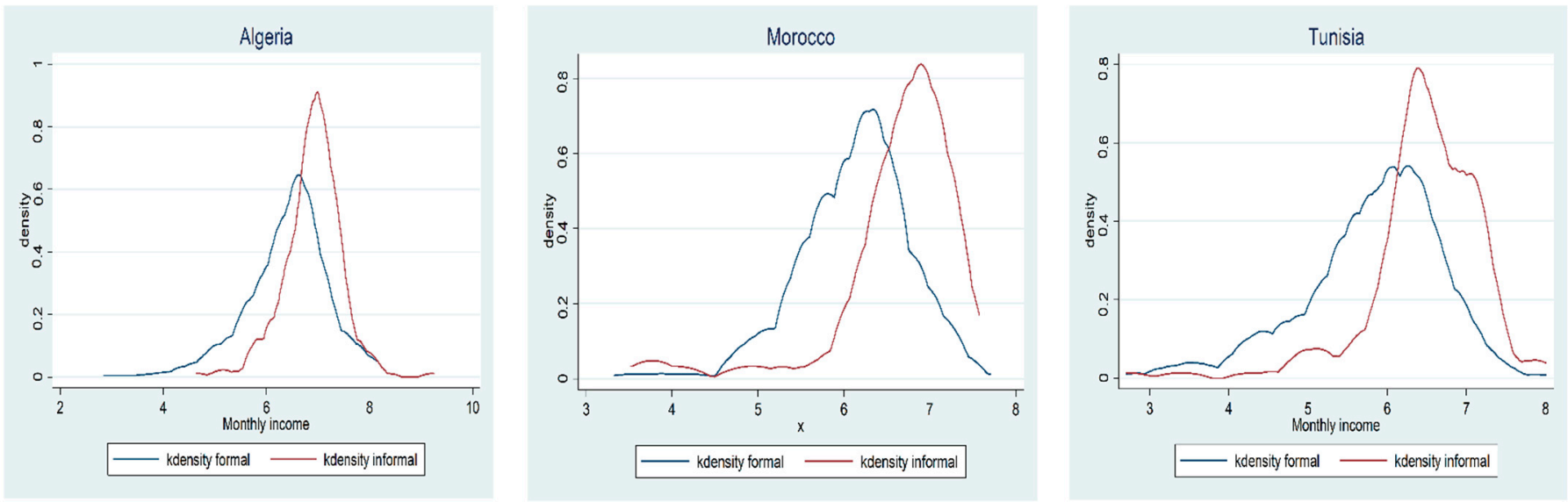

Figure A1. Densities of monthly log income. Source: Sahwa dataset using Stata.

\section{Notes}

1 The standard definition of conflict is "a contested incompatibility that concerns government and/or territory, where the use of armed force between two parties, of which at least one is the government of a state, results in at least 25 battle-related deaths in a calendar year." (Högbladh 2020)

2 For more details about Beveridgian social welfare, see Merouani et al. (2014) and Whiteside (2014).

3 Only employees with a permanent contract are eligible for unemployment insurance.

4 Contribution rate is variable according to the probability of having an accident at work and work injury.

5 The sample of workers by country is low, analyzing each country separately is less likely to provide consistent results.

6 For more details about the method of weighting, see Solon et al. (2015).

7 For more details on the logit model, see Merouani et al. (2016a).

8 One may think that the category of workers who want to avoid a reduction in their income do not choose informality but are concerned that they would be unable to provide for their families or maintain a lifestyle if they pay social security contributions. This is not valid in the case of our sample because these workers have a higher average monthly income (USD701) compared to those in the category who report that their employers refuse to insure them (USD451), and those who report that their employer is not insured (USD477). The highest average income was observed among those who declare they are not interested in social security (USD954).

9 Given the low sample size of workers by country, one should be cautious in interpreting these figures.

10 Workers who declare that they are not insured because they are not interested or to avoid a reduction in their income.

11 Workers who declare that the employers do not want to declare them or that they themselves are not enrolled in social security. The number of divorced and widowed respondents is very small in the sample.

For more details about the cross-tabulation of job satisfaction and informality, see Table A3 in Appendix A.

To what extent is religion important in your place of work?

To what extent is religion important in your commercial and financial transactions?

16 Having adventures and taking risks is important to this person; living an exciting life. The answers are ranked from 1 "This greatly resembles me" to 6 "Does not resemble me at all".

17 It is important to this person to take care of the people around them. The answers are ranked from 1 "This greatly resembles me" to 6 "Does not resemble me at all".

18 Workers who hold a "self-employment" job in a market-oriented establishment operated by a related person living in the same household, who cannot be regarded as partners, because their degree of commitment to the operation of the establishment, in terms of working time or other factors to be determined by national circumstances, are not at a level comparable to that of the head of the establishment (ILO 2003).

\section{References}

Adhikari, Binay, and Virginia E. O'Leary. 2013. Gender Differences in Risk Aversion: A Developing Nation's Case. Journal of Personal Finance 10: 122-47.

Alger, Ingela, and Donald Cox. 2013. The evolution of altruistic preferences: Mothers versus fathers. Review of Economics of the Household 81: 421-46. [CrossRef]

Assaad, Ragui. 2014. Making sense of Arab labor markets: The enduring legacy of dualism. IZA Journal of Labor E Development 3: 6. 
Auerbach, Paula, María Eugenia Genoni, and Carmen Pagès. 2007. Social Security Coverage and the Labor Market in Developing Countries. En Ligne. Available online: http:/ / repec.iza.org (accessed on 1 July 2018).

Balan, Jorge, Harley Linwood Browning, and Elizabeth Jelin. 1975. Men in a Developing Society: Geographic and Social Mobility in Monterrey. Annals of the Association of American Geographers 65: 576-78.

Banerjee, Biswajit. 1983. The Role of the Informal Sector in the Migration Process: A Test of Probabilistic Migration Models and Labour Market Segmentation for India. Oxford Economic Papers 35: 399-422. [CrossRef]

Bellache, Youghourta. 2010. L'économie Informelle en Algérie, une Approche par Enquête Auprès des Ménages—Le cas de Bejaia. Ph.D. thesis, 2010, Université de Bejaia, Algérie, Université Paris-Est Créteil, Paris, France.

Ben Braham, Mehdi, and Mohamed Ali Marouani. 2016. Pension Systems Contribution Determinants: A Cross Sectional Analysis on Tunisia. Available online: https:/ / umr-developpement-societes.univ-paris1.fr (accessed on 1 September 2020).

Ben Othman, Mouna, and Mohamed Ali Marouani. 2016. Labor Market Effects of Pension Reform: An Overlapping Generations General Equilibrium Model Applied to Tunisia. Available online: https:/ / erf.org.eg/wp-content/uploads (accessed on 1 September 2020).

Bommier, Antoine, and François Le Grand. 2014. Too risk averse to purchase insurance? A theoretical glance at the annuity puzzle. Journal of Risk and Uncertainty 48: 135-66. [CrossRef]

Castells, Manuel, and Alejandro Portes. 1989. World Underneath: The Origins, Dynamics, and Effects of the Informal Economy. In The Informal Economy: Studies in Advanced and Less Advanced Developed. Edited by A. Portes, M. Castells and Lauren A. Benton. Baltimore: John Hopkins University Press.

Chen, Martha Alter. 2012. The Informal Economy: Definitions, Theories and Policies. WIEGO Working Paper No. 1. Available online: https:/ / www.wiego.org/sites/default/files/migrated/publications/files/Chen_WIEGO_WP1.pdf (accessed on 1 July 2018).

De Mel, Suresh, David McKenzie, and Christopher Woodruff. 2013. The demand for, and consequences of, formalization among informal firms in Sri Lanka. American Economic Journal: Applied Economics 5: 122-50. [CrossRef]

De Soto, Hernando. 1989. The other Path: The Invisible Revolution in the Third World. New York: Harper \& Row.

Duggal, R. 2006. Need to universalise social security. Economic and Political Weekly 41: 3495-97.

Dupuis, Jean-Marc, Claire El Moudden, Nacer Eddine Hammouda, Anne Petron, Mehdi Ben Braham, and Ilham Dkhissi. 2011. L'impact des systèmes de retraite sur le niveau de vie des personnes âgées au Maghreb. Economie Et Statistique 441: 205-24.

Faillo, Marco, Daniela Grieco, and Luca Zarri. 2013. Legitimate punishment, feedback and the enforcement of cooperation. Games and Economic Behavior 77: 271-83. [CrossRef]

Falco, Paolo. 2013. Does risk matter for occupational choices? Experimental evidence from an african labour market. Labour Economics 28: 96-109. [CrossRef]

Fields, Gary S. 1975. Rural-urban migration, urban unemployment and underemployment, and job-search activity in LDCs. Journal of Development Economics 2: 165-87. [CrossRef]

Fields, Gary S. 1990. Labour market modelling and the urban informal sector: Theory and evidence. In The Informal Sector Revisited. Edited by D. Thurnham, B. Salome and A. Schwarz. Paris: OECD.

Sebastian, Galiani, and Federico Weinschelbaum. 2012. Modeling Informality Formally: Households And Firms. Economic Inquiry 50: 821-38.

Gatti, Roberta, Diego F. Angel-Urdinola, Joana Silva, and András Bodor. 2014. Striving for Better Jobs: The Challenge of Informality in the Middle East and North Africa. Washington, DC: The World Bank. [CrossRef]

Günther, Isabel, and Andrey Launov. 2012. Informal employment in developing countries Opportunity or last resort? Journal of Development Economics 97: 88-98. [CrossRef]

Gurr, Ted Robert. 1970. Why Men Rebel. Princeton: Princeton University Press.

Hart, Keith. 1973. Informal Income Opportunities and Urban Employment in Ghana. Journal of Modern African Studies 11: 61-89. [CrossRef]

Högbladh, Stina. 2020. UCDP Georeferenced Event Dataset Codebook, Version 20.1. Uppsala: Uppsala Conflict Data Program, Department of Peace and Conflict Research, Uppsala University, Available online: https://ucdp.uu.se/downloads/ged/ged201.pdf (accessed on 1 May 2021).

Huang, Gengzhi, Desheng Xue, and Bo Wang. 2020. Integrating Theories on Informal Economies: An Examination of Causes of Urban Informal Economies in China. Sustainability 12: 2738. [CrossRef]

ILO. 1972. Employment, Incomes and Equality: A Strategy for Increasing Productive Employment in Kenya. Geneva: ILO.

ILO. 2003. Guidelines Concerning a Statistical Definition of Informal Employment. Available online: https://www.ilo.org/wcmsp5 /groups/public/---dgreports/---stat/documents/normativeinstrument/wcms_087622.pdf (accessed on 1 July 2018).

Kaliciak, Anna, Radoslaw Kurach, and Walid Merouani. 2019. The Importance of Behavioural Factors for Pension Savings DecisionsCross-Country Evidence. Acta Oeconomica 69: 357-91. [CrossRef]

Kivimäki, Timo. 2021. The Fragility-Grievances-Conflict Triangle in the Middle East and North Africa (MENA): An Exploration of the Correlative Associations. Social Sciences 10: 120. [CrossRef]

Lopez, T. A. 1970. Migration and urban marginality in underdeveloped countries. Demographia y Economia, Juanaguato, Mexique 4.

Maloney, William F. 2004. Informality Revisited. World Development 32: 1159-78. [CrossRef]

Mansfield, Edward R., and Billy P. Helms. 1981. Detecting Multicollinearity. The American Statistican 36: $158-60$. 
Marshall, M. G., and G. Elzinga-Marshall. 2017. Global Report 2017. Conflict, Governance, and State Fragility. Vienna: Center for Systematic Peace.

Mazumdar, Dipak. 1981. The urban labor market and income distribution: Study on Malaysia. The Journal of Asian Studies 42: 227-29.

Merouani, W. 2014. Modélisation Des Dépenses Et Recettes Du Système Algérien Des Retraites. Sarrebruck: Editions Universitaires Européennes.

Merouani, Walid, Nacer-Eddine Hammouda, and Claire El Moudden. 2014. Le système algérien de protection sociale entre bismarckien et beveridgien. Cahiers du CREAD 2014: 107-8.

Merouani, Walid, Nacer Eddine Hammouda, and Claire El Moudden. 2016a. The Microeconomic Determinants of Demand for Social Security: Evidence from the Algerian Labour Market. Institutions and Economies 8: 25-61.

Merouani, Walid, Nacer Eddine Hammouda, and Claire El Moudden. 2016b. Les Nouveau déterminant de la demande de sécurité sociale: Le cas de la région d'Alger. Retraite et Société 73: 120-48.

Moser, Caroline O. N. 1978. Informal sector or petty commodity production: Dualism or dependence in urban development? World Development 6: 1041-64. [CrossRef]

Murphy, Ryan O., Kurt A. Ackermann, and Michel Handgraaf. 2011. Measuring social value orientation. Judgment E Decision Making 6: 771-81.

Perry, Guillermo E., Omar Arias, Pablo Fajnzylber, William F. Maloney, Andrew Mason, and Jaime Saavedra-Chanduvi. 2007. Informality: Exit and exclusion. Washington DC, USA: The World Bank.

Portes, A., M. Castells, and L. A. Benton. 1989. The Informal Economy: Studies in Advanced and Less Developed Countries. Baltimore: The John Hopkins University Press.

Razafindrakoto, Mireille, François Roubaud, and Jean-Michel Wachsberger. 2012. Travailler Dans Le Secteur Informel: Choix ou Contrainte ? Une Analyse de la Satisfaction Dans L'emploi au Vietnam. Available online: www.afd.fr (accessed on 1 November 2016).

Renana, Jhabvala. 1998. Social security for unorganised sector. Economic and Political Weekly 33: L7-L11.

Rhee, Chong-Hoon. 1986. A Study of the Path of Rural-Urban Migration in Korea. Unpublished Master's Thesis, Seoul National University, Seoul, Korea.

Shehu, Erin, and Björn Nilsson. 2014. Informal Employment among Youth: Evidence from 20 School-to-Work Transition Surveys. Geneva: International Labour Office.

Solon, Gary, Steven J. Haider, and Jeffrey M. Wooldridge. 2015. What Are We Weighting For? Journal of Human Resources 50: 301-16. [CrossRef]

Thaler, Richard. 2016. Misbehaving, the Making of Behavioural Economics. London: Penguin Books.

Tirole, J. 2017. Narrative, Imperative and Moral reasoning. In Proceedings of the conference of The Econometric society, Algiers, Algeria, 29 June-1 July.

Whiteside, Noel. 2014. The Beveridge Report and Its Implementation: A Revolutionary Project? Histoire@Politique 3: 24-37. [CrossRef] 